University of St. Thomas, Minnesota

UST Research Online

Accounting Faculty Publications

Accounting

2009

Stock Splits, Trading Continuity, and the Cost of Equity Capital

J. C. Lin

Louisiana State University - Shreveport

A. Singh

Case Western Reserve University

Wen Yu

University of St. Thomas, Minnesota, yu017469@stthomas.edu

Follow this and additional works at: https://ir.stthomas.edu/ocbacctpub

Part of the Accounting Commons

This Article is brought to you for free and open access by the Accounting at UST Research Online. It has been accepted for inclusion in Accounting Faculty Publications by an authorized administrator of UST Research Online. For more information, please contact asle4660@stthomas.edu. 


\title{
Stock splits, trading continuity, and the cost of equity capital ${ }^{\text {th }}$
}

\author{
Ji-Chai Lin ${ }^{\mathrm{a}, *}$, Ajai K. Singh ${ }^{\mathrm{b}}$, Wen $\mathrm{Yu}^{\mathrm{c}}$ \\ a Department of Finance, Louisiana State University, Baton Rouge, LA 70803, USA \\ ${ }^{\mathrm{b}}$ Case Western Reserve University, Cleveland, OH 44106, USA \\ c University of St. Thomas, Opus College of Business, Minneapolis, MN 55403, USA
}

\section{A R T I C L E I N F O}

\section{Article history:}

Received 17 April 2008

Received in revised form

27 August 2008

Accepted 9 September 2008

Available online 19 May 2009

\section{JEL classification:}

G12

G32

Keywords:

Stock splits

Trading continuity

Liquidity risk

Cost of equity capital

\begin{abstract}
A B S T R A C T
We hypothesize that managers use stock splits to attract more uninformed trading so that market makers can provide liquidity services at lower costs, thereby increasing investors' trading propensity and improving liquidity. We examine a large sample of stock splits and find that, consistent with our hypothesis, the incidence of no trading decreases and liquidity risk is lower following splits, implying a decline in latent trading costs and a reduced cost of equity capital. Further, split announcement returns are correlated with the improvements in both liquidity levels and liquidity risk. Our analysis suggests nontrivial economic benefits from liquidity improvements, with less liquid firms benefiting more from stock splits.
\end{abstract}

(c) 2009 Elsevier B.V. All rights reserved.

\section{Introduction}

Managers often claim that stock splits are intended to attract more investors and to improve stock liquidity (Dolley, 1933; Baker and Gallagher, 1980; Baker and Powell, 1993). Muscarella and Vetsuypens (1996) examine ADR solo-splits and find evidence supportive of the liquidity improvement argument. Similarly, Amihud, Mendelson, and Uno (1999) show that, in Japan, a firm's investor base and stock liquidity increase significantly when the firm reduces its stock's minimum trading unit

\footnotetext{
We thank Utpal Bhattacharya, Chun-Nan Chen, Adam Lei, Sandra Mortal, K.C. John Wei, and seminar participants at Louisiana State University, National Cheng Kung University, National Chiao Tung University, National Central University, and Peking University for comments and suggestions. We are especially grateful to Yakov Amihud (the referee), Bill Schwert (the editor), Shane Johnson, Srinivasan Krishnamurthy, Weimin Liu and Leonardo Madureira for their careful review and comments. We are responsible for any remaining errors.

* Corresponding author.

E-mail address: filin@lsu.edu (J.-C. Lin).
}

(i.e., the number of shares in a round lot). However, many studies question whether liquidity improves after stock splits. In fact, Copeland (1979), Conroy, Harris, and Benet (1990), Easley, O’Hara, and Saar (2001), and Gray, Smith, and Whaley (2003) show that while splits lower stock price levels, they raise bid-ask spreads rather than improving the stocks' liquidity. Also, Copeland (1979) and Lamoureux and Poon (1987) find that turnover decreases following stock splits, which leads them to surmise that "splits induce permanent reductions in liquidity."

The findings intrigue Easley, O'Hara, and Saar (2001, p. 25), who note that "stock splits remain one of the most popular and least understood phenomena in equity markets... why a split per se is necessary is unclear... empirical research has documented a wide range of negative effects such as increased volatility, larger proportional spreads and larger transaction costs following the splits. On balance, it remains a puzzle why companies ever split their shares."

In this paper, we offer a new perspective on the issue. Our premise is that non-trading reflects illiquidity. This 
premise is motivated by Lesmond, Ogden, and Trzcinka (1999), Lesmond (2005), Liu (2006), and Bekaert, Harvey, and Lundblad (2007). In particular, Lesmond, Ogden, and Trzcinka (1999) argue that informed investors will trade only if the value of information exceeds trading costs. Similarly, liquidity traders might refrain from trading if trading costs outweigh the improvement in portfolio allocation. Hence, the trading decision is endogenous and a function of trading costs, which are directly related to market-making costs. We do not observe trading costs or market-making costs; but ex post we can observe whether trades have occurred, and we can then infer the latent trading costs. Holding other things constant, greater incidence of no trading implies higher (unobservable) trading costs and lower liquidity. ${ }^{1}$

While the bid-ask spread is conventionally used to measure trading costs, it has a limitation-the bid and ask quotes are often for small-size trades, whereas a larger transaction size might need to be negotiated. As Liu (2006, p. 631) points out, liquidity can be generally described as "the ability to trade large quantities quickly at low cost with less price impact." This suggests that liquidity is multifaceted and might not be well represented by the bid-ask spread, either before or after a stock split. Similarly, because of the endogeneity of the trading decision, standard measures such as Amihud's (2002) illiquidity measure and Kyle's (1985) lambda, which focus on the price impacts of trades, might not be able to fully capture the illiquidity of non-trading, either before or after a split.

Thus, we propose the trading continuity improvement hypothesis to explain how a stock split might improve liquidity and why it could be beneficial to the firm. Our hypothesis posits that, for a firm facing some possibility of trading discontinuity or no trading, managers have incentives to use a stock split to attract more uninformed traders to participate in trading. Indeed, Schultz (2000) shows a significant increase in small trades following the splits. Further, Easley, O'Hara, and Saar (2001) document more uninformed trades-and more informed trades as well-after stock splits. ${ }^{2}$ More uninformed trading allows market makers to reduce their inventory holding costs and adverse information cost, which could lead to lower trading costs and liquidity improvements. In an improved liquidity environment, stock prices are less affected by shocks to market liquidity. Thus, our hypothesis predicts that, after stock splits, investors would face lower liquidity risk and require a lower liquidity premium, which in turn would reduce the cost of equity capital for the firm and increase firm value.

We use a large sample of NYSE/AMEX/Nasdaq stock splits to test our hypothesis. To measure the degree of trading discontinuity on each sample stock, we use Liu's (2006) LM12, the standardized turnover-adjusted number of days with zero trading volume over the prior 12

\footnotetext{
${ }^{1}$ We are indebted to the referee for directing us to this line of reasoning.

2 Their finding is consistent with Admati and Pfleiderer (1988), who suggest that, to camouflage their trades, informed traders would follow as uninformed trades increase.
}

months. Similar to Fama and French's (1996) size and book-to-market factors, Liu constructs a mimicking liquidity factor, $L I Q$, as the return difference between a low-liquidity portfolio (containing stocks with high LM12) and a high-liquidity portfolio (containing stocks with low LM12), and develops a liquidity-augmented CAPM (LCAPM). He shows that firms with greater liquidity risk earn higher returns, indicating that investors require a liquidity premium to compensate for the higher liquidity risk. Furthermore, he demonstrates that his LCAPM can explain the anomalies associated with firm size, book-tomarket, cash-flow-to-price, earnings-to-price, dividend yield, and long-run price reversals. Because of its explanatory power on the cross-section of stock returns, we use Liu's model to measure liquidity risk and the cost of equity capital for each of our sample stocks.

Consistent with our hypothesis, we find that the incidence of no trading decreases (implying lower latent costs of trading), liquidity risk is mitigated, and the cost of equity capital is reduced following stock splits. Further, the split announcement returns are correlated with improvements in both liquidity levels and liquidity risk. While firms with more frequent trading discontinuities benefit more from stock splits, those with daily trades benefit as well. ${ }^{3}$ On average, liquidity improvements reduce the cost of equity capital by $17.3 \%$, or $2.42 \%$ points per annum, suggesting that the economic benefits of stock splits are nontrivial.

It is worth pointing out that the prior literature suggests two possible reasons for the positive effects of splits on prices. The first is liquidity improvement, given the positive value-liquidity relation (e.g., Amihud and Mendelson, 1986). Alternatively, the positive price reaction could be explained by Brennan and Copeland's (1988) signaling proposition, which is based on the premise that splits raise transaction costs and hence serve as a costly signal of managers' private information. Our findings are consistent with the first explanation, and do not support the basis of Brennan and Copeland's (1988) signaling model because latent trading costs decline rather than increase after stock splits.

The rest of our study is organized as follows. Section 2 formally proposes the trading continuity improvement hypothesis for firms' stock split decisions. Section 3 presents Liu's (2006) liquidity measure. Section 4 discusses our sample selection and the characteristics of the sample firms. Section 5 presents empirical results of the effect of stock splits on liquidity. Section 6 presents evidence that stock splits lead to liquidity risk reduction, resulting in a lower cost of equity capital. Section 7 investigates whether the split announcement returns are correlated with the liquidity improvements. Section 8 contains our conclusions.

\footnotetext{
${ }^{3}$ For those firms with trades every day, the liquidity risk reduction following the split is significant. Although Liu's LM12 emphasizes trading discontinuity at the daily level and does not address intraday trading discontinuity (e.g., on an hourly basis), we conjecture that the liquidity risk reduction could be due to improvement in trading continuity at the intraday level.
} 


\section{The trading continuity improvement hypothesis}

Uninformed traders play an important role in determining stock liquidity. As Stoll (1989) points out, there are three components of market-making costs-order processing costs, inventory holding costs, and adverse information costs. The last component represents market makers' losses from trading with informed investors, which can be covered by gains from trading with uninformed investors. Thus, more uninformed trading could reduce both market makers' inventory holding costs and adverse information costs. This implies that managers can reduce trading costs for shareholders and improve their stock's liquidity if there is a corporate policy that can be used to attract more uninformed traders to participate in trading.

Stock splits appear to be such a corporate policy in that they can attract more uninformed traders for the following reasons. As Fama, Fisher, Jensen, and Roll (1969) point out, a stock split is usually preceded by a significant increase in stock price. By engaging in a split to lower the price level, managers can effectively make buying shares easier for small investors. Lakonishok and Lev (1987) also argue that stock splits are executed by firms that have enjoyed unusual growth in both earnings and stock prices, and that the main objective of the split appears to be to return the stock price to a "normal" range in the wake of the unusual growth. Similarly, So and Tse (2000) address the sociological aspects of maintaining a stable targetprice habit, and argue that one of the principal reasons for stock splits is to conform to the market norm. As Copeland (1979) suggests, there might be a certain clientele that prefers to buy stocks at a certain (lower) price range. ${ }^{4}$ This clientele is usually thought to be uninformed or small investors (see also Easley, O'Hara, and Saar, 2001). Harris (1996) and Angel (1997) suggest that another clientele that could be attracted by a stock split might be traders, who find it profitable to supply liquidity via limit orders due to split-induced increases in (proportional) tick size. Using NYSE non-public data, Lipson (1999) indeed shows that the use of limit orders slightly increases following the splits and that the realized execution cost of limit orders declines substantially. However, he finds that the realized execution cost for market orders increases.

Furthermore, managers could use stock splits to attract more analysts to follow their stocks. According to Brennan and Hughes (1991), splits could create incentives for brokerage houses to produce more information on split firms. Similarly, Schultz (2000) argues that splits give stockbrokers greater incentives to promote the stocks (see also Kadapakkam, Krishnamurthy, and Tse, 2005). Improved information production and promotion of the split firms could attract more investors to participate in stock trading.

In view of these reasons, we propose the trading continuity improvement hypothesis to explain firms' stock

\footnotetext{
${ }^{4}$ Interestingly, analyzing mutual fund share splits, Fernando, Krishnamurthy, and Spindt (1999) show that, relative to non-splitting matched funds, split funds experience significant increases in shareholders.
}

split decisions. It posits that firms facing some possibility of trading discontinuity can use stock splits to attract more uninformed trading. This enables market makers to provide liquidity services at lower cost following the splits. With lower trading costs, investors' propensity to trade increases. Thus, while the split-induced increase in uninformed trading contributes to trading continuity, the resulting lower trading costs further improve trading continuity after the splits.

Furthermore, as the liquidity environment improves, stock prices should become more resilient and less vulnerable to shocks to market liquidity. Consequently, investors face reduced liquidity risk and require a lower liquidity premium which, in turn, lowers the cost of equity capital for the firm, and the value of the firm should increase. Indeed, as many studies have documented, the market reacts positively to stock splits; see, e.g., Grinblatt, Masulis, and Titman (1984), Lamoureux and Poon (1987), and Ikenberry, Rankine, and Stice (1996).

To test our hypothesis, we focus on the following issues. First, do stock splits improve liquidity in terms of greater trading continuity? Second, do stock splits reduce the liquidity risk that investors face and lower firms' cost of equity capital? Third, given the importance of liquidity in asset pricing (see Amihud, Mendelson, and Pedersen, 2005), are split announcement returns related to improvements in both liquidity levels and liquidity risk?

In the following sections, we describe how we measure liquidity before and after the splits, collect our split sample, and conduct our analyses to address the above issues.

\section{Measuring stock liquidity}

Based on the premise that a greater incidence of no trading implies higher latent costs of trading and that non-trading reflects illiquidity, we measure stock liquidity using Liu's (2006) LMx, the standardized turnoveradjusted number of days with zero trading volume over the prior $x$ months. Specifically, Liu formulates his $L M x$ as

$L M x=[$ Number of zero daily volumes in prior $x$ months

$$
\left.+\frac{1 /(x \text {-month turnover })}{\text { Deflator }}\right] \times \frac{21 x}{\text { NoTD }},
$$

where " $x$-month turnover" is the stock's turnover in the prior $x$ months calculated as the sum of daily turnover over the prior $x$ months (daily turnover is the ratio of the number of shares traded on a day to the number of shares outstanding at the end of the day), NoTD is the total number of trading days in the market over the prior $x$ months, and Deflator is chosen such that

$$
0<\frac{1 /(x \text {-month turnover })}{\text { Deflator }}<1
$$

for all sample stocks (for example, Liu chooses a deflator of 11,000 in constructing his $L M 12$ ).

Liu (2006) shows that $L M x$ reflects multiple dimensions of liquidity, is highly correlated with conventional liquidity measures such as bid-ask spread, turnover, and price impact measures, and places particular emphasis on 
trading discontinuity. The measure uses the number of zero daily trading volumes over the prior $x$ months to capture the intuition that the absence of trading in a security indicates its degree of illiquidity. As expected, Liu shows that smaller firms and firms with high book-tomarket equity ratios, which tend to be less liquid, have high LM12. Also, compared to firms with low LM12, there is a significant liquidity premium associated with firms with high $L M 12$.

While $L M x$ emphasizes trading discontinuity at the daily level, trading discontinuity could also occur at the intraday level (e.g., on an hourly basis). Unfortunately, the measure does not explicitly take into account intraday trading discontinuity. As Liu (2006, p. 636) points out, " $L M x$ uses the pure number of zero daily trading volumes over the prior $x$ months to identify the least liquid stocks, but it relies on turnover to distinguish the most liquid among frequently traded stocks as classified by the pure number of zero trading volumes." Thus, for stocks that trade every day, it is possible that stock splits attract more trades (Schultz, 2000; Easley, O'Hara, and Saar, 2001), but that turnover decreases (Copeland, 1979; Lamoureux and Poon, 1987). That is, following the splits, there could be more trades, but the average trade size might not increase proportionately with the split factor, resulting in a lower turnover. In this case (for the more liquid firms with $L M x<1$ ), since $L M x$ is essentially determined by $1 /$ turnover, it might not show a split-induced improvement in intraday trading continuity, indicating that the measure has its limitations. Nevertheless, with zerovolume days as its main component, $L M x$ would sufficiently capture severe illiquidity, as manifested in nontrading.

\section{Data}

To test the trading continuity improvement hypothesis, we use a sample of 3,721 stock splits that occur during the 30-year period from 1975 to 2004. We identify this sample by searching through the Center for Research in Security Prices (CRSP) files for ordinary single-class common stocks with a split factor of one or higher, a pre-split price of $\$ 10$ or above, and the availability of both firm size (i.e., pre-split market value of equity) and the book value of equity on the Compustat files over the 1975-2004 period. Furthermore, we require each sample firm to have at least one year of daily trading volume data, both before and after its stock split, available on the CRSP files for computing our liquidity measure, $L M 12$. The split factor is the number of additional shares issued per existing share. For example, a split factor of one means a two-for-one split, i.e., investors receive one additional share for every old share they hold. To be included in our sample, a stock must have a share code of 10 or 11 and be a single-class stock, with the CRSP Factor to Adjust Price (FACPR) equal to or greater than one and equal to the CRSP Factor to Adjust Shares Outstanding (FACSHR). We require firm size and book equity so that we can determine in which firm size quartile and B/M (book-to-market equity ratio) quartile each split firm is. As we show in the next section, for each split firm, we choose a comparable (benchmark) firm, which is a non-split firm whose price at the end of month -1 (relative to the declaration month) is closest to that of the split firm among all non-split firms in the same size quartile and $\mathrm{B} / \mathrm{M}$ quartile as the split firm.

Of the 3,721 splits, 2,109 are for NYSE/AMEX stocks over the 1975-2004 sample period, and the remaining 1,612 are for Nasdaq stocks over the 1985-2004 sample period. A total of 3,399 , or $91.3 \%$, have a split factor equal to one; 269 , or $7.2 \%$, have a split factor greater than one and less than or equal to two; and the remaining 53, or $1.5 \%$, have a split factor above two. The highest split factor in our sample is 9 .

In terms of pre-split liquidity, denoted as preLM12, about $28.7 \%$, or 1,069 firms, have preLM $12 \geq 1$, and the remaining $71.3 \%$, or 2,652 firms, have preLM $12<1$. While the firms in the former subsample have at least one zerovolume day in the year prior to the splits, the firms in the latter subsample have trades every day. Our trading continuity improvement hypothesis postulates that, for firms with some possibility of trading discontinuity, managers could use stock splits to improve their stock's illiquidity. This suggests that the effects of stock splits on liquidity improvements would be greater for less liquid firms. For this reason, we carry out our analyses for the full sample as well as for the preLM12 subsamples.

Table 1 reports the mean and the median of pre-split firm characteristics for the full sample and for each subsample by stock exchange and by preLM12. For the full sample, the average pre-split price, measured at day -5 relative to the declaration date, is $\$ 58.23$, and the average split factor is 1.11 , i.e., shareholders receive 1.11 additional shares on average for every pre-split share they have. The average firm size prior to the splits is $\$ 4.55$ billion. The average book-to-market equity ratio is 0.373 , suggesting that the sample firms tend to have relatively high growth opportunities.

While the pre-split average prices and split factors are similar between the NYSE/AMEX and the Nasdaq subsamples, the Nasdaq stocks are generally smaller in terms of firm size. Further, the Nasdaq stocks also have an average book-to-market equity ratio of 0.287 , versus 0.438 for the NYSE/AMEX stocks. Due to the distinctions in firm characteristics and the differences in how trading volumes are reported, we control for the effect of the listing exchange while examining the effects of stock splits on liquidity.

Relative to firms with preLM12<1, firms with preLM12 $\geq 1$ are, on average, smaller ( $\$ 0.43$ billion vs. $\$ 6.21$ billion) and have a higher B/M (0.502 vs. 0.321). Furthermore, the pre-split number of shareholders is smaller as well (2,645 vs. 26,792). While the average firm in the preLM $12<1$ subsample splits their shares at a price of $\$ 65.57$, the less liquid firms with preLM12 $\geq 1$ tend to split their shares at $\$ 40.03$.

Table 2 reports changes in firm characteristics from before to after stock splits. For the full sample, the split lowers the average post-split share price, measured at day +5 relative to the ex-distribution date, to $\$ 29.94$ from $\$ 58.23$ prior to the splits. Consistent with the hypothesis that stock splits attract new investors (Lamoureux and 
Table 1

Pre-split sample characteristics.

This table reports the mean (median) values of firm characteristics prior to the split. Split factor (splitfactor) is the number of additional shares per old share issued. Pre-split share price (preprc) is the closing price or bid/ask average from CRSP at day -5 relative to the stock split declaration date. Pre-split market capitalization (presz) is market value in millions, and the pre-split book-to-market ratio (prebm) is the ratio of book equity value (Compustat item $60+$ item 74 ) to market value of equity at day -5 relative to the declaration date. Pre-split investor base (preinvestor) is the number of shareholders (in $1,000 \mathrm{~s}$, Compustat item 100) before the declaration month. Pre-split institutions (preinstitution) is the number of 13f institutions that hold stocks, and pre-split institutional ownership (preinslown) is 13f institutions' stock ownership from Thomson Financial in the calendar quarter before the split declaration. Pre-split turnover (preturn) is the average daily turnover from month -12 to month -1 relative to the declaration month. The daily turnover is the ratio of the number of shares traded to the number of shares outstanding at the end of the day from CRSP. The pre-split number of zero daily volumes (prezerovol) is the number of days with zero trading volume from CRSP from month -12 to month -1 relative to the declaration month. The presplit price run-up (prerunup) is the price run-up from day -120 to day -2 relative to the declaration date. We report the mean (median) values for the whole sample, the subsamples by exchange, and the subsamples by pre-split trading discontinuity (preLM12).

\begin{tabular}{|c|c|c|c|c|c|}
\hline & $\begin{array}{l}\text { Whole sample } \\
\qquad(N=3,721)\end{array}$ & $\begin{array}{c}\text { NYSE/AMEX } \\
(N=2,109)\end{array}$ & $\begin{array}{c}\text { Nasdaq } \\
(N=1,612)\end{array}$ & $\begin{array}{l}\text { preLM } 12 \geq 1 \\
(N=1,069)\end{array}$ & $\begin{array}{l}\text { preLM } 12<1 \\
(N=2,652)\end{array}$ \\
\hline splitfactor & $\begin{array}{l}1.112 \\
(1.000)\end{array}$ & $\begin{array}{l}1.119 \\
(1.000)\end{array}$ & $\begin{array}{l}1.104 \\
(1.000)\end{array}$ & $\begin{array}{l}1.160 \\
(1.000)\end{array}$ & $\begin{array}{l}1.093 \\
(1.000)\end{array}$ \\
\hline preprc & $\begin{array}{l}58.232 \\
(50.250)\end{array}$ & $\begin{array}{l}61.101 \\
(54.250)\end{array}$ & $\begin{array}{l}54.479 \\
(45.395)\end{array}$ & $\begin{array}{l}40.027 \\
(36.000)\end{array}$ & $\begin{array}{l}65.570 \\
(57.400)\end{array}$ \\
\hline presz $\left(10^{6}\right)$ & $\begin{array}{l}4550.009 \\
(640.845)\end{array}$ & $\begin{array}{l}5604.959 \\
(959.495)\end{array}$ & $\begin{array}{l}3169.804 \\
(415.216)\end{array}$ & $\begin{array}{l}431.226 \\
(107.712)\end{array}$ & $\begin{array}{l}6210.257 \\
(1259.089)\end{array}$ \\
\hline prebm & $\begin{array}{l}0.373 \\
(0.291)\end{array}$ & $\begin{array}{l}0.438 \\
(0.362)\end{array}$ & $\begin{array}{l}0.287 \\
(0.194)\end{array}$ & $\begin{array}{l}0.502 \\
(0.428)\end{array}$ & $\begin{array}{l}0.321 \\
(0.243)\end{array}$ \\
\hline preinvestor $\left(10^{3}\right)$ & $\begin{array}{l}20.646 \\
(2.766)\end{array}$ & $\begin{array}{l}32.018 \\
(5.048)\end{array}$ & $\begin{array}{l}4.046 \\
(1.051)\end{array}$ & $\begin{array}{l}2.645 \\
(1.247)\end{array}$ & $\begin{array}{l}26.792 \\
(4.148)\end{array}$ \\
\hline preinstitution & $\begin{array}{l}119.614 \\
(72.000)\end{array}$ & $\begin{array}{l}156.986 \\
(105.000)\end{array}$ & $\begin{array}{l}76.783 \\
(47.000)\end{array}$ & $\begin{array}{l}20.126 \\
(13.000)\end{array}$ & $\begin{array}{l}156.622 \\
(107.000)\end{array}$ \\
\hline preinslown & $\begin{array}{l}0.463 \\
(0.467)\end{array}$ & $\begin{array}{l}0.479 \\
(0.497)\end{array}$ & $\begin{array}{l}0.444 \\
(0.411)\end{array}$ & $\begin{array}{l}0.228 \\
(0.180)\end{array}$ & $\begin{array}{l}0.550 \\
(0.557)\end{array}$ \\
\hline preturn $\left(10^{-3}\right)$ & $\begin{array}{l}6.332 \\
(3.007)\end{array}$ & $\begin{array}{l}3.356 \\
(2.312)\end{array}$ & $\begin{array}{l}10.227 \\
(6.082)\end{array}$ & $\begin{array}{l}2.448 \\
(1.398)\end{array}$ & $\begin{array}{l}7.898 \\
(3.883)\end{array}$ \\
\hline prezerovol & $\begin{array}{l}9.956 \\
(0.000)\end{array}$ & $\begin{array}{l}4.731 \\
(0.000)\end{array}$ & $\begin{array}{l}16.792 \\
(0.000)\end{array}$ & $\begin{array}{l}34.557 \\
(12.000)\end{array}$ & $\begin{array}{l}0.039 \\
(0.000)\end{array}$ \\
\hline prerunup (\%) & $\begin{array}{l}40.262 \\
(20.698)\end{array}$ & $\begin{array}{l}23.760 \\
(15.558)\end{array}$ & $\begin{array}{l}61.853 \\
(30.129)\end{array}$ & $\begin{array}{l}42.950 \\
(21.382)\end{array}$ & $\begin{array}{l}39.179 \\
(20.294)\end{array}$ \\
\hline
\end{tabular}

Poon, 1987; Maloney and Mulherin, 1992; Mukherji, Kim, and Walker, 1997), the average number of shareholders significantly increases from 20,646 before the split to 24,982 after the split. The average number of institutional investors increases as well, from 119 to 131 . However, there is a slight decrease in average institutional share ownership, from $46.3 \%$ to $45.3 \%$. These results suggest that while stock splits attract new investors, existing shareholders appear to sell a portion of the shares they receive pursuant to the stock splits. Consequently, there are more investors holding the shares, on average, but the proportionate holding per investor seems to decline following the splits.

The average increase in investor base is particularly notable for the subsample of firms with preLM $12 \geq 1$, which changes from 2,645 pre-split shareholders to 6,893 post-split shareholders, a $160 \%$ increase! The preLM $12<1$ subsample increases from 26,792 pre-split shareholders to 31,150 post-split shareholders, a $16 \%$ increase. In the sections that follow, we will address the extent to which the increase in investor base following the splits contributes to the trading continuity improvement and to liquidity risk reduction. Also, consistent with Merton (1987), Mukherji, Kim, and Walker (1997) find that split announcement returns are positively related to the increase in the investor base. We will control for the increase in the investor base as well in testing our hypothesis that split announcement returns are correlated with liquidity improvements.

Table 2 also reports changes in liquidity based on Roll's (1984) spread, the Gibbs estimate of Roll's spread as suggested by Hasbrouck (2005), Amihud's (2002) price impact measure, and average daily turnover. ${ }^{5}$ For Roll's spread, Amihud's impact measure, and turnover, the presplit estimates are obtained from month -12 to month -1 relative to the declaration month, and the post-split estimates are from month 1 to month 12 relative to the ex-distribution month. Hasbrouck (2005) suggests that Gibbs estimate might not be reliable if the observation number of daily returns used in estimation is less than 50 . Hence, if the number of pre-split (post-split) return observations is less than 50 , we use the Gibbs estimate from one year before (after) the split year.

On average, both Roll's spread and the Gibbs estimate of Roll's spread increase significantly following the splits, which is consistent with Copeland (1979), Conroy, Harris, and Benet (1990), Easley, O'Hara, and Saar (2001), and Gray, Smith, and Whaley (2003). However, we find that average daily turnover is higher following the splits,

\footnotetext{
${ }^{5}$ For Gibbs estimate of Roll's spread, we obtain the pre- and postsplit estimates from Professor Hasbrouck's website: http://pages.stern. nyu.edu/ jhasbrou/.
} 
Table 2

Changes in sample characteristics after stock splits.

This table reports mean (median) changes in sample characteristics following the splits. Pre-split prc is the closing price or bid/ask average from CRSP at day -5 relative to the stock split declaration date, and post-split prc is at day 5 relative to the ex-distribution date. investor is the number of shareholders (in 1,000 s, Compustat item 100); the pre-split estimate is obtained before the declaration month and the post-split estimate after the ex-distribution month. institution is the number of $13 \mathrm{f}$ institutions, and inslown is $13 \mathrm{f}$ institutions' stock ownership from Thomson Financial; the pre-split estimate is obtained in the calendar quarter before the declaration and the post-split estimate after the ex-distribution. turnover is the average ratio of daily trading volume to the number of shares outstanding. For 1/(12-month turnover), the 12-month turnover is the sum of daily turnover over 12 months. Roll's Spread is measured as $\sqrt{-\operatorname{Cov}\left(r_{i, t}, r_{i, t-1}\right)}$. Following Harris (1990), we set Roll's spread $=0$ if $\operatorname{cov}\left(r_{i, t}, r_{i, t-1}\right)>0$. Following Hasbrouck (2005), we also provide Gibbs estimates of Roll's spread. Amihud's IM is $\left|r_{i, t}\right| /\left(p_{i, t} \times v o l_{i, t}\right)$, where $r_{i, t}$ is the daily return, $p_{i, t}$ is the closing price or bid/ask average, and $v o l_{i, t}$ is daily volume. For turnover, 1/(12-month turnover), Roll's spread, and Amihud's IM, the pre-split estimates are obtained from month -12 to month -1 relative to the declaration month and the post-split estimates are from month 1 to month 12 relative to the ex-distribution month. 12-month turnover is the sum of daily turnover over the 12 months. Stat. test reports the $t$-value ( $p$-value of the signed rank tests) for testing whether the mean (median) difference between post- and pre-split values is equal to zero.

\begin{tabular}{|c|c|c|c|c|c|c|c|c|c|}
\hline & \multicolumn{3}{|c|}{ Whole sample } & \multicolumn{3}{|c|}{ Subsample of preLM $12 \geq 1$} & \multicolumn{3}{|c|}{ Subsample of preLM $12<1$} \\
\hline & Pre-Split & Post-Split & Stat. test & Pre-Split & Post-Split & Stat. test & Pre-Split & Post-Split & Stat. test \\
\hline prc & $\begin{array}{l}58.232 \\
(50.250)\end{array}$ & $\begin{array}{l}29.940 \\
(26.250)\end{array}$ & $\begin{array}{l}-170.352^{\mathrm{a} * * *} \\
(<.0001)^{\mathrm{b}}\end{array}$ & $\begin{array}{l}40.027 \\
(36.000)\end{array}$ & $\begin{array}{l}20.739 \\
(19.000)\end{array}$ & $\begin{array}{l}-81.460^{\mathrm{a} * * *} \\
(<.0001)^{\mathrm{b}}\end{array}$ & $\begin{array}{l}65.570 \\
(57.400)\end{array}$ & $\begin{array}{l}33.648 \\
(29.750)\end{array}$ & $\begin{array}{l}-151.515^{\mathrm{a} * * *} \\
(<.0001)^{\mathrm{b}}\end{array}$ \\
\hline investor $\left(10^{3}\right)$ & $\begin{array}{l}20.646 \\
(2.766)\end{array}$ & $\begin{array}{l}24.982 \\
(3.500)\end{array}$ & $\begin{array}{l}19.359^{\mathrm{a} * * *} \\
(<.0001)^{\mathrm{b}}\end{array}$ & $\begin{array}{l}2.645 \\
(1.247)\end{array}$ & $\begin{array}{l}6.893 \\
(1.500)\end{array}$ & $\begin{array}{l}9.096^{\mathrm{a} * * *} \\
(<.0001)^{\mathrm{b}}\end{array}$ & $\begin{array}{l}26.792 \\
(4.148)\end{array}$ & $\begin{array}{l}31.150 \\
(5.357)\end{array}$ & $\begin{array}{l}17.093^{\mathrm{a} * * *} \\
(<.0001)^{\mathrm{b}}\end{array}$ \\
\hline institution & $\begin{array}{l}119.614 \\
(72.000)\end{array}$ & $\begin{array}{l}131.424 \\
(83.000)\end{array}$ & $\begin{array}{l}41.343^{\mathrm{a} * * *} \\
(<.0001)^{\mathrm{b}}\end{array}$ & $\begin{array}{l}20.126 \\
(13.000)\end{array}$ & $\begin{array}{l}24.501 \\
(16.000)\end{array}$ & $\begin{array}{l}23.090^{\mathrm{a} * * *} \\
(<.0001)^{\mathrm{b}}\end{array}$ & $\begin{array}{l}156.622 \\
(107.000)\end{array}$ & $\begin{array}{l}172.120 \\
(123.000)\end{array}$ & $\begin{array}{l}37.925^{\mathrm{a} * * *} \\
(<.0001)^{\mathrm{b}}\end{array}$ \\
\hline inslown & $\begin{array}{l}0.463 \\
(0.467)\end{array}$ & $\begin{array}{l}0.453 \\
(0.464)\end{array}$ & $\begin{array}{l}-2.838^{* * *} \\
(0.9810)\end{array}$ & $\begin{array}{l}0.228 \\
(0.180)\end{array}$ & $\begin{array}{l}0.234 \\
(0.188)\end{array}$ & $\begin{array}{l}5.451^{* * *} \\
(<.0001)\end{array}$ & $\begin{array}{l}0.550 \\
(0.557)\end{array}$ & $\begin{array}{l}0.536 \\
(0.548)\end{array}$ & $\begin{array}{l}-5.549^{* * *} \\
(<.0001)\end{array}$ \\
\hline turnover $\left(10^{-3}\right)$ & $\begin{array}{l}6.332 \\
(3.007)\end{array}$ & $\begin{array}{l}6.859 \\
(3.072)\end{array}$ & $\begin{array}{l}3.506^{* * *} \\
(<.0001)\end{array}$ & $\begin{array}{l}2.448 \\
(1.398)\end{array}$ & $\begin{array}{l}3.361 \\
(1.506)\end{array}$ & $\begin{array}{l}5.431^{* * *} \\
(<.0001)\end{array}$ & $\begin{array}{l}7.898 \\
(3.883)\end{array}$ & $\begin{array}{l}8.269 \\
(3.928)\end{array}$ & $\begin{array}{l}1.859^{*} \\
(0.0474)\end{array}$ \\
\hline 1/(12-month turnover) & $\begin{array}{l}2.230 \\
(1.316)\end{array}$ & $\begin{array}{l}2.147 \\
(1.286)\end{array}$ & $\begin{array}{l}-2.546^{* *} \\
(0.0330)\end{array}$ & $\begin{array}{l}4.311 \\
(2.827)\end{array}$ & $\begin{array}{l}3.964 \\
(2.634)\end{array}$ & $\begin{array}{l}-3.211^{* * *} \\
(0.0010)\end{array}$ & $\begin{array}{l}1.391 \\
(1.020)\end{array}$ & $\begin{array}{l}1.414 \\
(1.007)\end{array}$ & $\begin{array}{l}1.721^{*} \\
(0.6985)\end{array}$ \\
\hline Roll's Spread (\%) & $\begin{array}{l}0.319 \\
(0.000)\end{array}$ & $\begin{array}{l}0.421 \\
(0.000)\end{array}$ & $\begin{array}{l}9.963^{* * *} \\
(<.0001)\end{array}$ & $\begin{array}{l}0.656 \\
(0.236)\end{array}$ & $\begin{array}{l}0.682 \\
(0.342)\end{array}$ & $\begin{array}{l}1.054 \\
(0.0168)\end{array}$ & $\begin{array}{l}0.183 \\
(0.000)\end{array}$ & $\begin{array}{l}0.316 \\
(0.000)\end{array}$ & $\begin{array}{l}12.707^{* * *} \\
(<.0001)\end{array}$ \\
\hline Gibbs (\%) & $\begin{array}{l}0.531 \\
(0.356)\end{array}$ & $\begin{array}{l}0.706 \\
(0.529)\end{array}$ & $\begin{array}{l}21.832^{* * * *} \\
(<.0001)\end{array}$ & $\begin{array}{l}0.815 \\
(0.494)\end{array}$ & $\begin{array}{l}0.978 \\
(0.707)\end{array}$ & $\begin{array}{l}7.371^{* * *} \\
(<.0001)\end{array}$ & $\begin{array}{l}0.414 \\
(0.324)\end{array}$ & $\begin{array}{l}0.594 \\
(0.487)\end{array}$ & $\begin{array}{l}26.774^{* * *} \\
(<.0001)\end{array}$ \\
\hline Amihud's IM $\left(10^{-7}\right)$ & $\begin{array}{l}4.954 \\
(0.206)\end{array}$ & $\begin{array}{l}3.159 \\
(0.111)\end{array}$ & $\begin{array}{l}-1.998^{*} \\
(<.0001)\end{array}$ & $\begin{array}{l}16.469 \\
(4.876)\end{array}$ & $\begin{array}{l}10.372 \\
(2.730)\end{array}$ & $\begin{array}{l}-1.951^{*} \\
(<.0001)\end{array}$ & $\begin{array}{l}0.313 \\
(0.064)\end{array}$ & $\begin{array}{l}0.251 \\
(0.038)\end{array}$ & $\begin{array}{l}-2.998^{* * *} \\
(<.0001)\end{array}$ \\
\hline
\end{tabular}

***, **, $*$ Significant at the $1 \%, 5 \%$, and $10 \%$ level, respectively, for the $t$-tests.

a The $t$-value is based on the difference in the log post-split versus log pre-split values.

b The $p$-value of the signed rank test is based on the difference in the log post-split versus log pre-split values.

especially for the less liquid subsample of firms with preLM12 $\geq 1$. For the subsample of firms with preLM12 $<1$, the evidence of turnover increase is weak. Consistent with Copeland (1979) and Lamoureux and Poon (1987), we find that the average turnover decreases after the splits for our NYSE/AMEX subsample, although it increases for our Nasdaq subsample. Similarly, Amihud's (2002) illiquidity measure shows a slight decrease in the price impact of trades following the splits. Thus, based on turnover and Amihud's illiquidity measure, there is weak evidence that stock splits improve liquidity.

In the next section, we present the results based on LM12. As Liu (2006) argues, it can capture multiple dimensions of liquidity and should thus be able to better reflect split-induced liquidity changes.

\section{Liquidity and the split factor}

\subsection{Evidence of liquidity improvement}

We use Liu's (2006) LM12, the standardized turnover-adjusted number of days with zero trading volume over 12 months, to measure liquidity. To show the effects of stock splits on liquidity, we use two approaches. The first is to compare each sample firm's pre-split LM12, measured over month -12 through month -1 relative to the split declaration month, and the post-split LM12, measured over month +1 through month +12 relative to the ex-distribution month. The second approach compares each sample firm to a benchmark firm, which is a non-split firm whose price at the end of month -1 (relative to the declaration month) is closest to that of the split firm among all non-split firms (ordinary common stocks) in the same size quartile and B/M quartile as the split firm. For each split firm, we define non-split firms as those firms that have no stock split in the window of two years before the split firm's split declaration date through two years following the split firm's split distribution. Following Fama and French (1993), we obtain the quartile cutoff points of firm size and of book-to-market equity ratio based on NYSE stocks. This second approach allows us to control for marketwide liquidity changes. Since the two approaches produce very similar results, we report in Table 3 only the results of the benchmark-adjusted approach, and give a brief summary of the results of the first approach below.

The pre-split average $L M 12$ is 9.94 , indicating that the average split firm has 9.94 turnover-adjusted no-trade days in the year prior to the split. The post-split average 
Table 3

The effect of stock splits on trading continuity.

This table reports the effects of stock splits on trading discontinuity, measured by Liu's (2006) LM12, the standardized turnover-adjusted number of zero daily trading volumes over 12 months, which is defined as

$$
\text { LM12 }=\left[\text { Number of zero daily volumes in } 12 \text { months }+\frac{1 /(12-\text { month turnover })}{\text { Deflator }}\right] \times \frac{21 \times 12}{\text { NoTD }} \text {. }
$$

Number of zero daily volumes in 12 months is the number of days with zero trading volume over the 12 months. 12-month turnover is the sum of daily turnover over the 12 months. Deflator is set at 11,000 such that $0<\frac{1 /(12 \text {-month turnover) }}{\text { Deflator }} 1$ for each stock (Liu, 2006). NoTD is the number of trading days in the market over the 12 months. Pre-split measure (preLM12), post-split measure (postLM12), and change in LM12 (chgLM12) are the benchmark-adjusted measures (the difference between a split firm's LM12 and that of its benchmark firm). Pre-split $L M 12$ is from month - 12 to month -1 relative to the stock split declaration month, and post-split LM12 is from month 1 to month 12 relative to the stock split ex-distribution month. The excess change in trading continuity (chgLM12) is the difference between the benchmark-adjusted postLM12 and preLM12. For each split firm, we choose a benchmark firm that is a non-split firm whose price at the end of month -1 (relative to the declaration month) is closest to that of the split firm among all non-split firms in the same size quartile and B/M quartile as the split firm. The $t$-values in parentheses assume independence across firms; and in the brackets are the $t$-values with autoregressive error correction standard error, assuming that the errors (i.e., the deviations from the mean) of the variable estimates follow an AR(1) process.

\begin{tabular}{|c|c|c|c|c|c|c|}
\hline & $\begin{array}{l}\text { Whole } \\
\text { sample }\end{array}$ & $\begin{array}{l}\text { Subsample of } \\
\text { preLM } 12 \geq 1\end{array}$ & $\begin{array}{l}\text { Subsample of } \\
\text { preLM } 12<1\end{array}$ & $\begin{array}{l}\text { Subsample of } \\
\text { splitfactor }=1\end{array}$ & $\begin{array}{l}\text { Subsample of } \\
\text { splitfactor }=(1,2)\end{array}$ & $\begin{array}{l}\text { Subsample of } \\
\text { splitfactor }>2\end{array}$ \\
\hline \multirow[t]{3}{*}{ preLM12 } & 0.109 & $8.396^{* * *}$ & $-2.898^{* * *}$ & -0.248 & 3.210 & $8.245^{*}$ \\
\hline & $(0.21)$ & $(4.73)$ & $(-9.82)$ & $(-0.46)$ & $(1.36)$ & (1.95) \\
\hline & [0.19] & [4.47] & {$[-9.82]$} & {$[-0.45]$} & [1.33] & [1.41] \\
\hline \multirow[t]{3}{*}{ postLM12 } & $-4.765^{* * *}$ & $-9.219^{* * *}$ & $-3.149^{* * *}$ & $-4.529^{* * *}$ & $-7.083^{* * *}$ & $-8.602^{*}$ \\
\hline & $(-10.11)$ & $(-5.99)$ & $(-10.14)$ & $(-9.41)$ & $(-3.25)$ & $(-2.00)$ \\
\hline & {$[-9.63]$} & {$[-5.77]$} & {$[-10.09]$} & {$[-8.81]$} & {$[-3.34]$} & {$[-1.95]$} \\
\hline \multirow[t]{3}{*}{ chgLM12 } & $-4.874^{* * *}$ & $-17.615^{* * *}$ & $-0.251^{* *}$ & $-4.281^{* * *}$ & $-10.294^{* * *}$ & $-16.848^{* * *}$ \\
\hline & $(-15.39)$ & $(-16.94)$ & $(-2.26)$ & $(-13.83)$ & $(-6.07)$ & $(-3.36)$ \\
\hline & {$[-13.92]$} & {$[-15.95]$} & {$[-2.34]$} & {$[-12.65]$} & {$[-6.58]$} & {$[-2.82]$} \\
\hline $\begin{array}{l}\text { Proportion of stocks with } \\
\text { chgLM } 12<0\end{array}$ & 0.513 & 0.812 & 0.404 & 0.506 & 0.567 & 0.705 \\
\hline$(p \text {-value })^{a}$ & $(<.0001)$ & $(<.0001)$ & $(<.0001)$ & $(<.0001)$ & $(<.0001)$ & $(<.0001)$ \\
\hline
\end{tabular}

***, **, ${ }^{*}$ Significant at the $1 \%, 5 \%$, and $10 \%$ level, respectively, for the $t$-tests.

a The $p$-value is based on the signed rank test for the null hypothesis that $\operatorname{chgLM12}=0$.

LM12 is 4.94, suggesting that the split firms, on average, experience a decrease of five no-trade days following the splits. The average change in LM12 (chgLM12) is significantly different from zero and about $62.9 \%$ of the sample firms experience a decrease in turnover-adjusted no-trade days. The correlations between chgLM12 and the changes in Roll's spread and between chgLM12 and the changes in the Gibbs estimate of Roll's spread are 0.13 and 0.15 , respectively. Both correlations are significant at the $1 \%$ level. The correlation between chgLM12 and the changes in Amihud's illiquidity measure is stronger at 0.20 . These correlations suggest that firms with greater reduction in no-trade days tend to experience a larger decline in Roll's spread and in the price impact of trades as well.

Table 3 shows that the pre-split LM12 of the sample firms is, on average, insignificantly different from that of the benchmark firms, indicating that prior to stock splits, the degree of trading discontinuity of split firms is similar to that of comparable non-split firms. Following the splits, the average LM12 of the sample firms is lower than that of the benchmark firms by 4.76 turnover-adjusted zerovolume days, which is significantly different from zero. This suggests that the split firms have a lower incidence of no trading than the benchmark firms in the post-split period. Furthermore, the sample firms' excess change in LM12 from the pre- to post-split period (i.e., the difference between the post-split benchmark-adjusted LM12 and the pre-split benchmark-adjusted LM12) shows a sig- nificant decrease of 4.87 turnover-adjusted no-trade days. The results suggest that liquidity improves following stock splits, which is consistent with our trading continuity improvement hypothesis.

We next use LM1 (the standardized turnover-adjusted number of zero daily trading volumes over one month) to illustrate and compare the pattern of trading discontinuity for the split firms and their benchmark firms. Specifically, Fig. 1 contrasts the pre-split average $L M 1$ of both samples (from month -24 through month -1 relative to the split declaration month) and the post-split average LM1 (from month +1 through month +24 relative to the exdistribution month). It illustrates that the post-split average LM1 of the split firms is lower than their pre-split average $L M 1$. It also shows that the post-split average $L M 1$ of the split firms is lower than that of their benchmark firms. Furthermore, the picture reveals that the effects of stock splits on reducing trading discontinuity are long term, lasting at least 24 months after the splits. Therefore, the liquidity improvement following stock splits is not a shortterm or a transitory phenomenon.

Table 3 also provides the subsample results by pre-split liquidity. The 1,069 sample firms with preLM $12 \geq 1$ have 8.39 more turnover-adjusted no-trade days, on average, than their benchmark firms before the splits; after the splits, they have 9.21 fewer turnover-adjusted no-trade days than their benchmark firms. Thus, on average, the subsample firms experience a significant excess reduction 


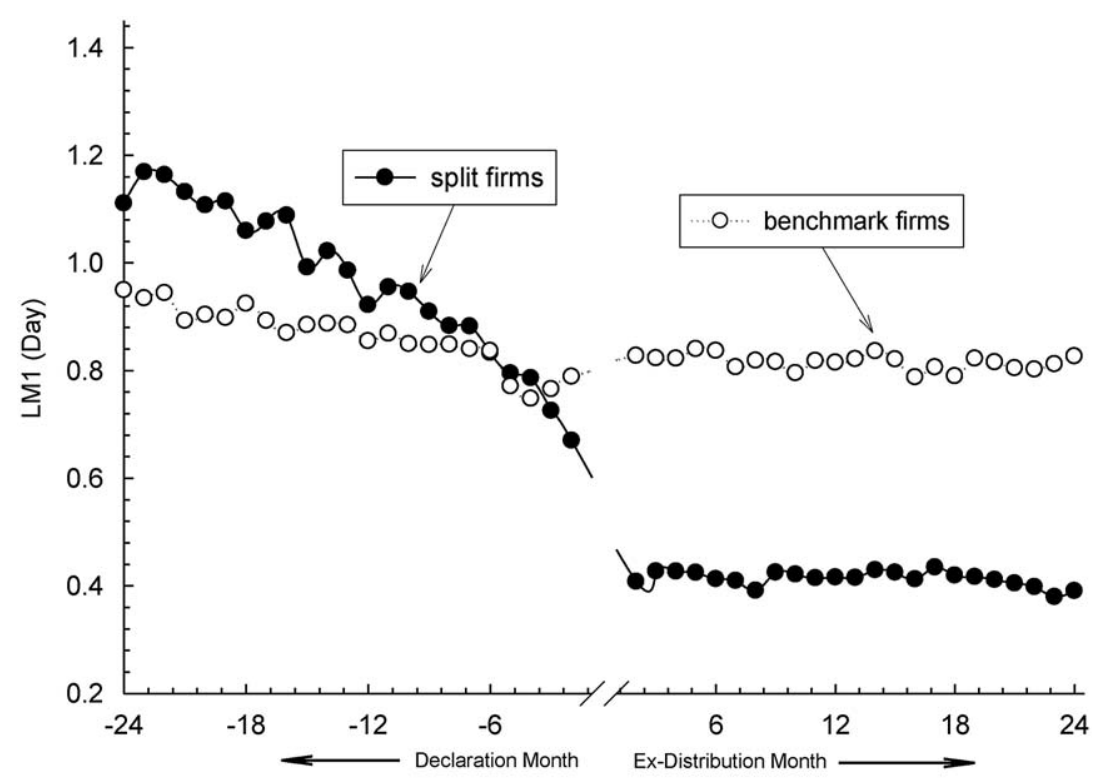

Relative Month

Fig. 1. Pre-split and post-split $L M 1$ of the split firms vs. their benchmark firms.

This figure plots the pre-split average $L M 1$ from month -24 to -1 relative to the stock split declaration month and the post-split average $L M 1$ from month 1 to 24 relative to the ex-distribution month for the split firms and their benchmark firms. For each split firm, we choose a benchmark firm that is a nonsplit firm whose price at the end of month -1 (relative to the declaration month) is closest to that of the split firm among all non-split firms in the same size quartile and B/M quartile as the split firm. $L M 1$ is the standardized turnover-adjusted number of zero daily trading volumes over one month (Liu, 2006). The estimate is

$$
\begin{aligned}
L M 1= & {[\text { Number of zero daily volumes in one month }} \\
& \left.+\frac{1 /(\text { one-month turnover })}{\text { Deflator }}\right] \times \frac{21 \times 1}{\text { NoTD }} .
\end{aligned}
$$

Number of zero daily volumes in one month is the number of days with zero trading volume over one month. One-month turnover is the sum of daily turnover over the month. Daily turnover is the ratio of the number of shares traded on a day to the number of shares outstanding at the end of the day. Deflator is set at 480,000 such that

$$
0<\frac{1 / \text { (one-month turnover })}{\text { Deflator }}<1
$$

for each stock (Liu, 2006). NoTD is the number of trading days in the market over the month.

of $17.61(t$-value $=-16.94)$ turnover-adjusted no-trade days, compared to their counterparts.

Similarly, the average firm in the preLM $12<1$ subsample experiences a significant excess reduction of 0.25 ( $t$-value $=-2.26)$ in $L M 12$ following the splits, relative to their benchmark firms. Thus, the more actively traded subsample also shows a significant reduction in trading discontinuity following the splits.

We also examine the subsample results by split factor. As the split factor increases from one to between one and two, and then to higher than two, the average number of turnover-adjusted no-trade days prior to the splits rises from 8.92 to 17.99 , and then to 34.60 , respectively. The numbers imply that firms appear to choose a higher split factor when their stocks face more frequent trading discontinuities.

On average, following the splits, the sample firms with a split factor equal to one experience an excess reduction of 4.28 days of turnover-adjusted no-trade days (excess with respect to their benchmark firms). The excess reduction is more pronounced-an average decrease of 10.29 days-for the sample stocks with a split factor between one and two, and the excess reduction further increases to 16.84 days for the sample stocks with a split factor greater than two. The excess reductions in LM12 for the three groups are all statistically significant. The results suggest that firms choosing a higher split factor seem to experience more trading continuity improvement following the splits.

Thus, our results from the subsample analyses are consistent with the trading continuity improvement hypothesis. We next use cross-sectional regression analyses to further investigate whether pre-split trading discontinuity is one of the determinants of the split factor, and also to check the robustness of our finding that choosing a higher split factor leads to a greater trading continuity improvement.

\subsection{Is pre-split liquidity a determinant of the split factor?}

Our trading continuity improvement hypothesis argues that firms whose stocks have higher $L M 12$, i.e., a greater incidence of no trading, could use a higher split factor to 
attract more trading from uninformed investors. The hypothesis thus predicts that, ceteris paribus, the split factor is positively related to pre-split $L M 12$.

Lakonishok and Lev (1987) and So and Tse (2000) argue that managers choose a split factor to return the price level to a "preferred" range. This implies that the higher the pre-split price, the higher the split factor must be to return the price level to a certain range. Furthermore, Dyl and Elliott (2006) argue that lower share prices are a characteristic of firms owned by so-called small investors, and that higher share prices are a characteristic of large firms. Their argument suggests that, holding other things constant, large firms would choose a smaller split factor.

To test our hypothesis that pre-split liquidity is a determinant of the split factor, we use the following regression model:

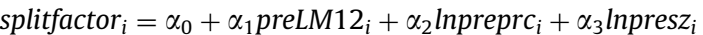

$$
\begin{aligned}
& +\alpha_{4} \text { Inprebm }_{i}+\alpha_{5} \text { prerunup }_{i}+\alpha_{6} \text { lnpreinvestor }_{i} \\
& +\alpha_{7} \text { lnpreinslown }_{i}+\alpha_{8} \text { exchdummy }_{i}+e_{i}
\end{aligned}
$$

The dependent variable, splitfactor, is the number of additional shares issued per old shares. The model allows us to test the relation between splitfactor and preLM12, which is the pre-split LM12 from month -12 to month -1 relative to the declaration month, while controlling for the following variables: Inpreprc, the log value of pre-split stock price; Inpresz, the log value of pre-split market capitalization; Inprebm, the log value of pre-split book-tomarket equity ratio at day -5 relative to the stock split declaration date; prerunup, the pre-split stock price runup from days -120 to -2 before the split declaration day (see Grinblatt, Masulis, and Titman, 1984); Inpreinvestor, the $\log$ value of the pre-split number of shareholders before the declaration month; Inpreinslown, the log value of the pre-split institutional share ownership in the calendar quarter before the split declaration; and exchdummy, an indicator variable for the exchange listing, which is equal to one if the sample stock is listed on Nasdaq and zero otherwise. We have also considered Inpreinsl, the log value of the number of institutional investors, and found that it has no significant effect. Furthermore, it has a correlation of 0.91 with $\log$ firm size, lnpresz. To avoid multicollinearity, we do not include it in our set of control variables. Of the 3,721 sample firms, 3,164 have all these control variables available for the regression analysis. Table 4 reports the regression results.

According to model 1 in the table, the split factor is significantly and positively related to preLM12. Thus, the regression results are consistent with our hypothesis that, ceteris paribus, firms choose a higher split factor when their stocks face more frequent trading discontinuities.

Model 1 also shows that the split factor is significantly and positively related to the pre-split price level and the book-to-market equity ratio, but negatively related to firm size, the pre-split price run-up, and institutional share ownership. Thus, holding other things constant, larger firms and firms with higher institutional ownership tend
Table 4

Cross-sectional analysis of the split factor.

This table reports the cross-sectional relation between the split factor (splitfactor, the number of additional shares per old share issued) and pre-split liquidity (preLM12, the pre-split $L M 12$ from month -12 to month -1 relative to the declaration month). For the subsample relations, we set preLM12_D1 = preLM12 if preLM12 $\geq 1$, otherwise preLM12_D1 $=0$; and preLM12_D0 = preLM12 if preLM12 $<1$, otherwise preLM12_D0 $=0$. We control for firm characteristics, including Inpreprc the log pre-split stock price; Inpresz, the log pre-split market capitalization; Inprebm, the log pre-split book-to-market equity ratio at day -5 relative to the declaration date; prerunup, the pre-split price run-up from day -120 to day -2 relative to the declaration date; Inpreinvestor, the log pre-split investor base before the declaration month; Inpreinslown, the log pre-split institutional share ownership in the calendar quarter before the split declaration; and exchdummy, an indicator variable equal to one if the sample stock is listed on the Nasdaq, and zero otherwise. The $t$ -

\begin{tabular}{|c|c|c|}
\hline \multirow[b]{2}{*}{ Model } & \multicolumn{2}{|c|}{ Dependent variable: splitfactor } \\
\hline & 1 & 2 \\
\hline preLM12 & $\begin{array}{l}\mathbf{0 . 0 0 1 6}^{* * *} \\
(3.71)\end{array}$ & \\
\hline preLM12_D1 & & $\begin{array}{l}0.0017^{* * *} \\
(3.82)\end{array}$ \\
\hline preLM12_D0 & & $\begin{array}{l}0.0687 \\
(1.39)\end{array}$ \\
\hline Inpreprc & $\begin{array}{l}0.6292^{* * *} \\
(25.21)\end{array}$ & $\begin{array}{l}0.6292^{* * *} \\
(25.22)\end{array}$ \\
\hline Inpresz & $\begin{array}{l}-0.0890^{* * *} \\
(-9.44)\end{array}$ & $\begin{array}{l}-0.0879^{* * *} \\
(-9.30)\end{array}$ \\
\hline Inprebm & $\begin{array}{l}0.0274^{* *} \\
(2.48)\end{array}$ & $\begin{array}{l}0.0274^{* *} \\
(2.47)\end{array}$ \\
\hline prerunup & $\begin{array}{l}-0.0354^{* * *} \\
(-3.33)\end{array}$ & $\begin{array}{l}-0.0354^{* * *} \\
(-3.33)\end{array}$ \\
\hline Inpreinvestor & $\begin{array}{l}0.0022 \\
(0.32)\end{array}$ & $\begin{array}{l}0.0020 \\
(0.30)\end{array}$ \\
\hline Inpreinslown & $\begin{array}{l}-0.1109^{* * *} \\
(-9.20)\end{array}$ & $\begin{array}{l}-0.1108^{* * *} \\
(-9.19)\end{array}$ \\
\hline exchdummy & $\begin{array}{l}0.0275 \\
(1.41)\end{array}$ & $\begin{array}{l}0.0281 \\
(1.45)\end{array}$ \\
\hline intercept & $\begin{array}{l}-0.8601^{\text {**** }} \\
(-10.23)\end{array}$ & $\begin{array}{l}-0.8699^{* * *} \\
(-10.31)\end{array}$ \\
\hline Adj. $R^{2}$ & 0.1907 & 0.1910 \\
\hline$N$ & 3,164 & 3,164 \\
\hline
\end{tabular}
values are given below the coefficient estimates.

$* * *, * * *$ Significant at the $1 \%, 5 \%$, and $10 \%$ level, respectively.

to choose a lower split factor to maintain a higher target price level, which is consistent with Dyl and Elliott's (2006) observation noted above.

Model 2 in Table 4 examines the subsample relation between the split factor and pre-split liquidity. We set preLM12_D1 = preLM12 if preLM12 $\geq 1$, otherwise pre$L M 12 \_D 1=0$; and preLM12_D0 = preLM12 if preLM12 $<1$, otherwise preLM12_D0 $=0$.

It follows that preLM12 = preLM12_D1+preLM12_D0. The results indicate that the pre-split liquidity level is a determinant of the split factor only for the less liquid firms. The finding is reasonable because, for the firms that have trades every day, illiquidity is not an imminent problem. Consequently, for the preLM12<1 subsample, the pre-split liquidity level is not important in setting the split factor. Conversely, the less liquid firms, which face greater illiquidity, choose a higher split factor. 


\subsection{The relation between changes in liquidity and the split factor}

If firms facing more frequent trading discontinuities tend to choose a higher split factor, does doing so lead to greater post-split liquidity improvement? To answer this question, we use the following cross-sectional regression analysis:

$$
\begin{aligned}
\operatorname{chgLM12}_{i}= & \beta_{0}+\beta_{1} \text { splitfactor }_{i}+\beta_{2}{\text { preLM } 12_{i}+\beta_{3} \text { Inpreprc }_{i}} \\
& +\beta_{4} \text { lnpresz }_{i}+\beta_{5} \text { Inprebm }_{i}+\beta_{6} \text { prerunup }_{i} \\
& +\beta_{7} \text { Inpreinvestor }_{i}+\beta_{8} \text { Inchginvestor }_{i} \\
& +\beta_{9} \text { Inpreinslown }_{i}+\beta_{10} \text { exchdummy }_{i}+\delta_{i}
\end{aligned}
$$

The dependent variable, chgLM12, is the difference between post- and pre-split LM12. While our focus is on the relation between chgLM12 and splitfactor, we are also interested in exploring which types of firms have more liquidity improvement from stock splits. In addition to the seven firm characteristic variables in Eq. (1), Eq. (2) includes Inchginvestor, the difference between the log post-split number of shareholders and the log pre-split number of investors, which allows us to check the extent to which the increase in investor base contributes to liquidity improvement. The equation also includes preLM12, with which we expect to measure the extent to which less liquid firms experience greater liquidity improvement.

Table 5 reports the regression results. Model 1 shows that chgLM12 is significantly and negatively related to splitfactor, indicating that a greater reduction in turnoveradjusted no-trade days is associated with a higher split factor. Model 2 shows that the relation holds for both subsamples by preLM12. Thus, consistent with the trading continuity improvement hypothesis, firms choosing a higher split factor experience greater liquidity improvement.

The regression results also reveal that chgLM12 is significantly and positively related to Inpreprc, but negatively related to preLM12, Inpresz, and prerunup. This suggests that larger firms, firms with a lower pre-split price level, and firms with a higher pre-split price runup-and especially higher pre-split trading discontinuityexperience greater liquidity improvement following the splits.

However, contrary to our expectation, Inchginvestor is insignificant, suggesting that, ceteris paribus, the extent of liquidity improvement is not related to the increase in investor base. Notice that the way we measure chgLM12 focuses on the long-term effects of trading - from one year before to one year after the splits-which excludes the effects of short-term trading from the split announcement month to the ex-distribution month. This focus allows us to minimize the short-term effects of information contained in the split announcement and any ex-distribution effects on trading. It is possible that the trading contributed by the increase in investor base occurs largely during this short period, and thus is not picked up by $\operatorname{chgLM} 12$.

\section{Changes in liquidity risk}

The trading continuity improvement hypothesis asserts that as stock splits attract more uninformed investors to participate in trading, market makers could
Table 5

Cross-sectional analysis of changes in liquidity.

This table reports the cross-sectional relation between chgLM12, the difference between log post-split $L M 12$ and log pre-split $L M 12$, and splitfactor. For the subsample relations, we set splitfactor_D1 = splitfactor if preLM12 $\geq 1$, otherwise splitfactor_D $1=0$; and splitfactor_D $0=$ splitfactor if preLM $12<1$, otherwise splitfactor_DO $=0$. We include a set of control variables, including preLM12, the log pre-split LM12 from month -12 to month -1 relative to the declaration month; Inpreprc, the log presplit stock price; Inpresz, the log pre-split market capitalization; lnprebm, the $\log$ pre-split book-to-market equity ratio at day -5 relative to the declaration date; prerunup, the pre-split price run-up from day -120 to day -2 relative to the declaration date; Inpreinvestor, the log pre-split investor base before the declaration month; Inpreinslown, the log presplit institutional share ownership in the calendar quarter before the split declaration; and exchdummy, an indicator variable equal to one if the sample stock is listed on the Nasdaq and zero otherwise. Also

\begin{tabular}{|c|c|c|}
\hline \multirow[b]{2}{*}{ Model } & \multicolumn{2}{|c|}{ Dependent variable: chgLM12 } \\
\hline & 1 & 2 \\
\hline splitfactor & $\begin{array}{l}-2.0948^{* * *} \\
(-6.60)\end{array}$ & \\
\hline splitfactor_D1 & & $\begin{array}{l}- \text { 3.4978 }^{* * *} \\
(-9.57)\end{array}$ \\
\hline splitfactor_D0 & & $\begin{array}{l}-0.9010^{* *} \\
(-2.56)\end{array}$ \\
\hline preLM12 & $\begin{array}{l}-0.4906^{* * *} \\
(-63.82)\end{array}$ & $\begin{array}{l}-0.4737^{* * *} \\
(-59.65)\end{array}$ \\
\hline Inpreprc & $\begin{array}{l}2.5430^{* * *} \\
(5.20)\end{array}$ & $\begin{array}{l}2.7112^{* * * *} \\
(5.58)\end{array}$ \\
\hline Inpresz & $\begin{array}{l}-0.3471^{* *} \\
(-2.02)\end{array}$ & $\begin{array}{l}-0.6020^{* * *} \\
(-3.47)\end{array}$ \\
\hline Inprebm & $\begin{array}{l}0.0290 \\
(0.15)\end{array}$ & $\begin{array}{l}0.0777 \\
(0.40)\end{array}$ \\
\hline prerunup & $\begin{array}{l}-0.9428^{* * *} \\
(-4.92)\end{array}$ & $\begin{array}{l}-0.9738^{* * *} \\
(-5.13)\end{array}$ \\
\hline Inpreinvestor & $\begin{array}{l}-0.0330 \\
(-0.27)\end{array}$ & $\begin{array}{l}-0.0598 \\
(-0.49)\end{array}$ \\
\hline Inchginvestor & $\begin{array}{l}0.0297 \\
(0.13)\end{array}$ & $\begin{array}{l}0.0111 \\
(0.05)\end{array}$ \\
\hline Inpreinslown & $\begin{array}{l}0.3895^{*} \\
(1.77)\end{array}$ & $\begin{array}{l}0.0552 \\
(0.25)\end{array}$ \\
\hline exchdummy & $\begin{array}{l}-0.4640 \\
(-1.34)\end{array}$ & $\begin{array}{l}-0.3023 \\
(-0.88)\end{array}$ \\
\hline intercept & $\begin{array}{l}-4.9345^{* * *} \\
(-3.22)\end{array}$ & $\begin{array}{l}-4.8679^{* * *} \\
(-3.21)\end{array}$ \\
\hline Adj. $R^{2}$ & 0.6681 & 0.6739 \\
\hline$N$ & 3,130 & 3,130 \\
\hline
\end{tabular}
included is inchginvestor, the difference between the log post-split number of shareholders and the log pre-split number of investors. The $t-$ values are given below the coefficient estimates.

${ }^{* * *},{ }^{* *},{ }^{*}$ Significant at the $1 \%, 5 \%$, and $10 \%$ level, respectively.

provide liquidity services at lower costs, which increases investors' propensity to trade. This improvement in the liquidity environment would make stock prices more resilient and less subject to impact from shocks to market liquidity. Consequently, investors would face lower liquidity risk and require a lower liquidity premium, which in turn leads to a lower cost of equity capital for the split firms. In this section, we test this prediction on changes in liquidity risk.

\subsection{Evidence of a reduction in liquidity risk}

Liu (2006) proposes a two-factor liquidity-augmented CAPM (LCAPM) in which, in addition to the market 
portfolio, stock returns are also related to a mimicking liquidity factor, LIQ. Similar to Fama and French's (1996) size factor, $S M B$, and $\mathrm{B} / \mathrm{M}$ factor, $H M L, L I Q$ is the return difference between a low-liquidity portfolio (containing stocks with high LM12) and a high-liquidity portfolio (containing stocks with low LM12). ${ }^{6}$ Specifically, the LCAPM posits that the expected excess return on stock $i$ can be expressed as

$E\left(r_{i}\right)-r_{f}=\beta_{i m}\left[E\left(r_{m}\right)-r_{f}\right]+\beta_{i l} E(L I Q)$,

where $E\left(r_{m}\right)$ is the expected return on the market portfolio, $E(L I Q)$ is the expected value of the mimicking liquidity factor, and $\beta_{i m}$ and $\beta_{i l}$ are firm $i$ 's factor loadings. As Liu (2006) demonstrates, this two-factor LCAPM performs better than Fama and French's (1996) three-factor model and Pastor and Stambaugh's (2003) asset pricing model in explaining the cross-section of stock returns. ${ }^{7}$ In particular, while the LCAPM can explain the size and the B/M effects, both the Fama-French and the Pastor-Stambaugh models cannot explain the liquidity premium associated with firms with high LM12. The LCAPM can also explain anomalies associated with the cash-flow-to-price ratio, dividend yield, earnings-to-price ratio, and long-term contrarian investment strategies, as shown by Liu (2006).

Thus, given its usefulness in explaining the crosssection of stock returns, we use Liu's LCAPM to measure the liquidity risk of each split firm and also to examine how it changes from before to after a stock split. First, we run the following time-series regression for each split firm:

$$
\begin{aligned}
r_{i t}-r_{f t}= & \alpha_{i, 0}+\alpha_{i, 1} D_{t}+\left(\beta_{i m, 0}+\beta_{i m, 1} D_{t}\right)\left(r_{m t, i}-r_{f t, i}\right) \\
& +\left(\beta_{i l, 0}+\beta_{i l, 1} D_{t}\right) L I Q_{t, i}+\varepsilon_{i t},
\end{aligned}
$$

where $r_{i t}$ is the monthly return of split firm $i$ at time $t ; r_{f t}$ is the risk-free rate at time $t ; D_{t}=1$ if $t$ is in the post-split period and $D_{t}=0$ otherwise; $\beta_{i m, 0}$ and $\beta_{i l, 0}$ are the presplit factor loadings on the market portfolio and the liquidity factor, respectively; $\beta_{i m, 1}$ and $\beta_{i l, 1}$ are the differences between the post- and pre-split factor loadings on the market portfolio and the liquidity factor, respectively; $\alpha_{i, 0}$ is the pre-split abnormal return; and $\alpha_{i, 1}$ is the difference between the post- and pre-split abnormal return. To avoid the announcement effect, the ex-date effect, and potential information leakage prior to the split, we run the regression in Eq. (4) for each firm for $t$ from month -24 to month -2 prior to the split declaration month and from month +2 to month +24 after the exdistribution month.

Next, we use the benchmark-adjusted return as the dependent variable and re-run the regression for each split firm, i.e.,

$$
\begin{aligned}
r_{i t}-r_{b i t}= & \alpha_{i, 0}+\alpha_{i, 1} D_{t}+\left(\beta_{i m, 0}+\beta_{i m, 1} D_{t}\right)\left(r_{m t, i}-r_{f t, i}\right) \\
& +\left(\beta_{i l, 0}+\beta_{i l, 1} D_{t}\right) L I Q_{t, i}+\varepsilon_{i t},
\end{aligned}
$$

\footnotetext{
${ }^{6}$ We thank Liu for providing us his liquidity factor, LIQ. For the detailed construction of $L I Q$, see Liu (2006, pp. 650-651).

${ }^{7}$ Pastor and Stambaugh (2003) suggest that liquidity risk can be measured by return sensitivity to market liquidity. However, their measure does not capture the liquidity risk stemming from trading discontinuity; instead, it captures the illiquidity related to price impacts of trades.
}

where $r_{b i t}$ is the monthly return of split firm $i$ 's benchmark firm, $\alpha_{i, 0}$ and $\alpha_{i, 1}$ are firm $i$ 's excess alphas (excess with respect to the benchmark firm), and $\beta_{i m, 0}, \beta_{i l, 0}, \beta_{i m, 1}$, and $\beta_{i l, 1}$ are its excess betas. For each split firm, we again choose a benchmark firm that is a non-split firm whose price at the end of month -1 (relative to the declaration month) is closest to that of the split firm among all nonsplit firms in the same size quartile and $\mathrm{B} / \mathrm{M}$ quartile as the split firm. This benchmark-adjusted approach allows us to mitigate the effects of possible marketwide movements in liquidity risk.

Table 6 reports both estimation results. To ensure that our factor loadings are estimated with sufficient observations, we exclude firms that have fewer than 12 (nonmissing) monthly returns available in either the pre-split or the post-split period. For the whole sample, the average of the $\alpha_{i, 0}$ estimates is $3.12 \%$, which is consistent with earlier findings of price run-ups prior to the splits. While the average of the pre-split market beta $\beta_{i m, 0}$ is 1.0417 , the mean of the pre-split liquidity beta is -0.1302 . On average, the split firms have higher pre-split market betas than the benchmark firms by 0.1258 . The average excess $\beta_{i l, 0}$ is insignificantly different from zero, suggesting that, on average, the split firms and their benchmark firms have similar pre-split liquidity betas. After the splits, however, the split firms experience a significant reduction in liquidity risk - the average $\beta_{i l, 1}$ is -0.2624 ( $t$-value $=$ -7.05 ) and the average excess $\beta_{i l, 1}$ is -0.3343 ( $t$-value $=$ -7.22 ). For the whole sample, $56.0 \%$ of the split firms show excess $\beta_{i l, 1}<0$. For the preLM12 $\geq 1$ subsample, $59.4 \%$ of the firms have excess $\beta_{i l, 1}<0$ and for the preLM $12<1$ subsample, $54.8 \%$ of the firms exhibit excess $\beta_{i l, 1}<0$. The results indicate that the majority of the sample firms, relative to their benchmark firms, experience a reduction in liquidity beta. The results are thus consistent with our trading continuity improvement hypothesis, which posits that as stock splits improve the liquidity environment, investors face lower liquidity risk.

Note that, to adjust for possible dependence in the $\beta_{i l, 1}$ estimates across firms, we sort and average the estimates by ex-date in calendar time (e.g., if two firms have the same ex-date, we average their $\beta_{i l, 1}$ ) to obtain a time series of $\beta_{i l, 1}$ estimates. Then, following Fama and French (2002), we obtain the autoregressive error correction standard error of the mean, assuming that the errors (i.e., the deviations from the mean) of the $\beta_{i l, 1}$ estimates follow an $\mathrm{AR}(1)$ process. We do the same autoregressive error correction for the other regression coefficients. In most cases, the $\mathrm{AR}(1)$ parameters are indeed significantly negative and, after the correction, the Durbin-Watson statistics are equal to 2.0, suggesting no more first-order correlation. For comparison, Table 6 also includes $t$-values under the assumption that the coefficient estimates are independent across firms.

The effects of stock splits on market betas are marginal. The average $\beta_{i m, 1}$ is -0.0637 ( $t$-value $=-1.86$ ), and the average excess $\beta_{i m, 1}$ is -0.0793 ( $t$-value $=-1.73$ ). The results suggest that liquidity improvement also leads to a slight reduction in market betas, which implies that the reduction in liquidity risk following the splits is not offset by the change in market betas. Scholes and Williams 
Table 6

Changes in liquidity risk.

This table reports the results of the following time-series regression, which is run for each split firm for $t$ from month -24 to month -2 prior to the split declaration month and from month +2 to month +24 after the ex-distribution month:

$$
\begin{aligned}
r_{i t}-r_{f t}= & \alpha_{i, 0}+\alpha_{i, 1} D_{t}+\left(\beta_{i m, 0}+\beta_{i m, 1} D_{t}\right)\left(r_{m t, i}-r_{f t, i}\right) \\
& +\left(\beta_{i l, 0}+\beta_{i l, 1} D_{t}\right) L I Q_{t, i}+\varepsilon_{i t},
\end{aligned}
$$

where $D_{t}=1$ if $t$ is in the post-split period, and $D_{t}=0$ otherwise; $\beta_{\text {im } 0}$ and $\beta_{i l, 0}$ are the pre-split betas on the market portfolio and the liquidity factor, respectively; $\beta_{i m, 1}$ and $\beta_{i l, 1}$ are the differences between the postand pre-split betas on the market portfolio and the liquidity factor, respectively; $\alpha_{i, 0}$ is the pre-split abnormal return; and $\alpha_{i, 1}$ is the difference between the post- and pre-split abnormal return. We also report the results of the regression that replaces dependent variable $r_{i t}-r_{f t}$ by $r_{i t}-r_{b i t}$, the benchmark-adjusted return. In this case, the results show firm $i$ 's excess $\alpha$ 's and $\beta$ 's over its benchmark firm. To ensure that our factor loadings are estimated with sufficient observations, we exclude from the report firms that have fewer than 12 (non-missing) monthly returns available in either the pre-split or the post-split period. The $t$-values in parentheses assume independence across firms; and in the brackets are the t-values with autoregressive error correction standard error, assuming that the errors (i.e., the deviations from the

\begin{tabular}{|c|c|c|c|c|c|c|}
\hline \multicolumn{7}{|c|}{ Panel A: The whole sample $(N=3,706)$} \\
\hline $\begin{array}{l}\text { Dependent } \\
\text { variable }\end{array}$ & $\alpha_{i, 0}$ & $\alpha_{i, 1}$ & $\beta_{i m, 0}$ & $\beta_{i m, 1}$ & $\beta_{i l, 0}$ & $\beta_{i l, 1}$ \\
\hline \multirow[t]{3}{*}{$r_{i t}-r_{f t}$} & 0.0312 & -0.0252 & 1.0417 & -0.0637 & -0.1302 & -0.2624 \\
\hline & $(51.20)$ & $(-32.93)$ & $(49.03)$ & $(-2.32)$ & $(-5.06)$ & $(-8.19)$ \\
\hline & [40.98] & {$[-29.46]$} & [40.38] & {$[-1.86]$} & {$[-3.73]$} & {$[-7.05]$} \\
\hline \multirow[t]{3}{*}{$r_{i t}-r_{b i t}$} & 0.0165 & -0.0091 & 0.1258 & -0.0793 & -0.0093 & -0.3343 \\
\hline & $(22.05)$ & $(-9.13)$ & $(4.85)$ & $(-2.21)$ & $(-0.29)$ & $(-8.16)$ \\
\hline & [20.39] & {$[-8.63]$} & [4.38] & {$[-1.73]$} & {$[-0.63]$} & {$[-7.22]$} \\
\hline \multicolumn{7}{|c|}{$\begin{array}{l}\text { Panel B: Subsample results by pre-split trading discontinuity } \\
\text { preLM12 } \geq 1(N=1,063)\end{array}$} \\
\hline \multirow[t]{3}{*}{$r_{i t}-r_{f t}$} & 0.0246 & -0.0217 & 1.0975 & -0.1191 & 0.4058 & -0.4696 \\
\hline & $(24.16)$ & $(-15.68)$ & $(24.39)$ & $(-2.18)$ & $(7.64)$ & $(-6.72)$ \\
\hline & [21.96] & {$[-14.88]$} & [24.23] & {$[-2.09]$} & [7.51] & {$[-6.51]$} \\
\hline \multirow[t]{3}{*}{$r_{i t}-r_{\text {bit }}$} & 0.0095 & -0.0041 & 0.1889 & -0.0252 & 0.4009 & -0.4913 \\
\hline & (6.99) & $(-2.12)$ & $(3.31)$ & $(-0.34)$ & $(6.00)$ & $(-5.75)$ \\
\hline & [6.77] & {$[-1.97]$} & [3.32] & {$[-0.39]$} & [5.47] & {$[-6.04]$} \\
\hline \multicolumn{7}{|c|}{ preLM12<1 $(N=2,643)$} \\
\hline \multirow[t]{3}{*}{$r_{i t}-r_{f t}$} & 0.0339 & -0.0267 & 1.0192 & -0.0414 & -0.3459 & $-\mathbf{0 . 1 7 9 0}$ \\
\hline & $(45.51)$ & $(-29.03)$ & $(43.09)$ & $(-1.31)$ & $(-12.36)$ & $(-5.12)$ \\
\hline & [36.67] & [ $[-25.49]$ & [34.86] & {$[-1.28]$} & {$[-9.54]$} & {$[-4.71]$} \\
\hline \multirow[t]{3}{*}{$r_{i t}-r_{b i t}$} & 0.0189 & -0.0109 & 0.1032 & -0.0986 & -0.1560 & -0.2781 \\
\hline & $(21.44)$ & $(-9.38)$ & (3.59) & $(-2.40)$ & $(-4.40)$ & $(-5.99)$ \\
\hline & [19.75] & {$[-8.90]$} & [3.36] & {$[-2.23]$} & {$[-3.98]$} & {$[-5.24]$} \\
\hline
\end{tabular}
mean) of the coefficient estimates follow an AR(1) process.

(1977) show that CAPM beta estimates are biased downward for infrequently traded stocks and biased upward for stocks traded very frequently. Our results show that trading continuity improves following the splits, suggesting that the market beta estimates should increase following the splits if the "true" market betas do not change. Instead, we find that the market beta estimates slightly decrease. It is possible that the slight decrease in the average market beta is simply due to a mean-reverting tendency (see, e.g., Blume, 1975).

How much would the cost of equity capital be reduced for the split firms because investors face lower liquidity risk and require a lower liquidity premium? Since we use monthly data, we estimate the cost of equity capital reduction per annum by compounding $\beta_{i l, 1} E(L I Q)$ for 12 months. During the sample period from 1975 through $2004, E(L I Q)$ is about $0.76 \%$ per month, which is very similar to Liu's estimate (2006, Table 5) of a monthly mean of LIQ over $1964-2003$ of $0.749 \%$. Thus, an average split-induced reduction in liquidity risk by 0.2624 translates into an average reduction of 2.42 percentage points per annum in the cost of equity capital for the split firms. This is a sizable reduction-a $17.3 \%$ reduction in the cost of equity capital-because the average pre-split cost of equity capital of the split firms is about $13.99 \%$ per annum (by Eq. (3), we have $r_{f}=0.49 \%, E\left(r_{m}\right)-r_{f}=0.678 \%$, and $E(L I Q)=0.76 \%)$.

Fig. 2 illustrates the month-by-month liquidity risk estimates from month -24 prior to the stock split declaration month to month +24 after the ex-distribution month for the split firms and for their benchmark firms. Following Ball and Kothari (1989), we obtain the monthby-month liquidity risk estimates by running a crosssectional regression,

$r_{i t}-r_{f t}=\alpha_{t}+\beta_{m, t}\left(r_{m t, i}-r_{f t, i}\right)+\beta_{l, t} L I Q_{t, i}+\varepsilon_{i t}$,

for each event month. The process allows us to obtain an aggregate measure of liquidity risk $\beta_{l, t}$ in each event month $t$ for the sample firms and for their benchmark firms. As Ball and Kothari (1989) point out, the advantage of the technique is to measure risks, which can shift during the event period. Fig. 2 shows that (1) the postsplit liquidity risk estimates of the split firms are lower than their pre-split estimates, and (2) while the pre-split liquidity risk estimates of the split firms are not much different from those of the benchmark firms, the split firms' post-split liquidity risk estimates are lower than their counterparts' estimates. Thus, the cross-sectional, month-by-month liquidity estimates confirm our timeseries, firm-by-firm liquidity risk estimates.

\subsection{Would firms with no zero-volume days benefit from stock splits?}

One might still be concerned about the following question: Would more liquid firms (e.g., those with no zero-volume days) benefit from stock splits? To address this question, we examine the changes in liquidity risk in the preLM12 subsamples.

As shown in Panel B of Table 6, the average pre-split market beta of the high- trading-discontinuity firms is 1.0975, which is slightly higher than 1.0192 for the lowtrading-discontinuity subsample. As expected, the two subsamples have very different pre-split liquidity betas: 0.4058 ( $t$-value $=7.64$ ) for the firms with high pre-split trading discontinuity versus -0.3459 ( $t$-value $=-12.36)$ for those with low pre-split trading discontinuity. This is consistent with the notion that investors face high (low) liquidity risk in firms with high (low) trading discontinuity.

Interestingly, both subsamples experience significant reductions in liquidity risk following the splits. The reduction is greater for the high-trading-discontinuity subsample-the average $\beta_{i l, 1}$ is $-0.4696(t$-value $=-6.72)$ 


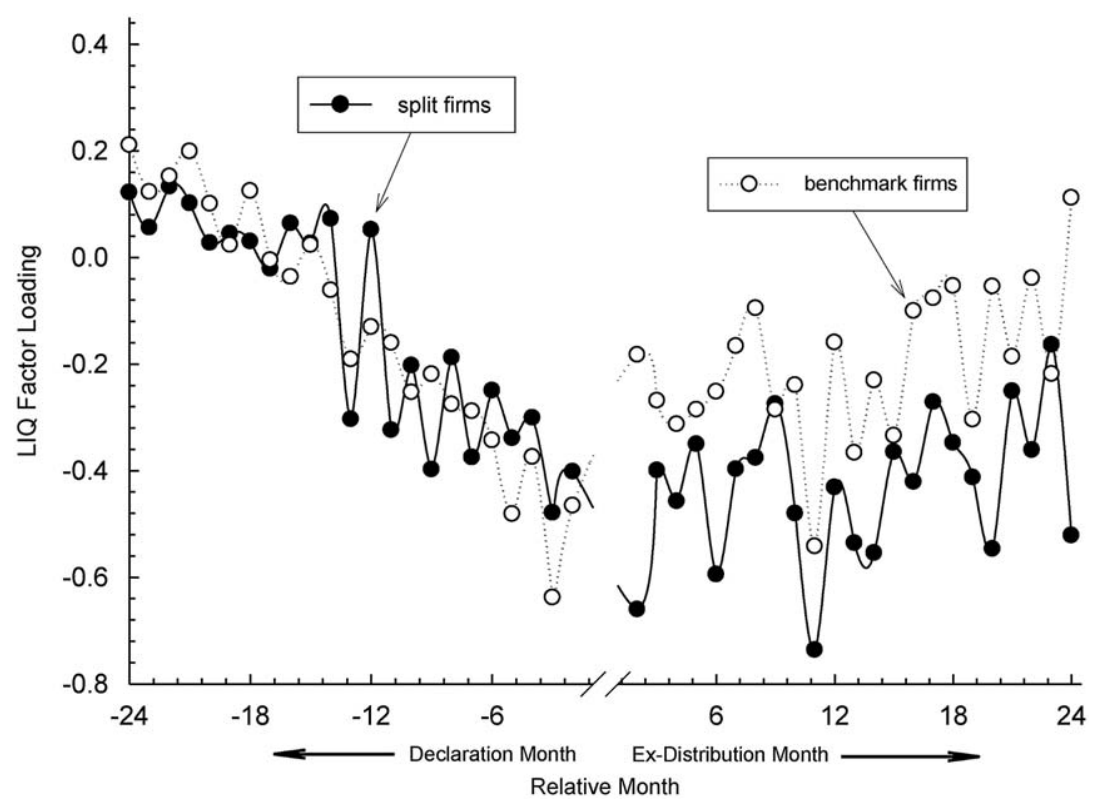

Fig. 2. Pre-Split and post-split liquidity risk of the split firms vs. their benchmark firms.

This figure plots the pre-split liquidity risk estimates from month -24 to -1 relative to the stock split declaration month and the post-split liquidity risk estimates from month 1 to 24 relative to the ex-distribution month for the split firms and their benchmark firms. For each split firm, we choose a benchmark firm that is a non-split firm whose price at the end of month -1 (relative to the declaration month) is closest to that of the split firm among all non-split firms in the same size quartile and B/M quartile as the split firm.

Following Ball and Kothari (1989), we obtain the month-by-month liquidity risk estimates by running a cross-sectional regression,

$$
r_{i t}-r_{f t}=\alpha_{t}+\beta_{m, t}\left(r_{m t, i}-r_{f t, i}\right)+\beta_{l, t} L Q_{t, i}+\varepsilon_{i t}
$$

for each event month in the pre-split period and in the post-split period. The process allows us to obtain an aggregate measure of liquidity risk, $\beta_{l, t}$, in each event month $t$ for the sample firms and their benchmark firms. As Ball and Kothari (1989) point out, the advantage of the technique is to measure risks, which can shift during the event period.

and the average excess $\beta_{i l, 1}$ is -0.4913 ( $t$-value $\left.=-5.75\right)$. For the low-trading-discontinuity subsample, the average $\beta_{i l, 1}$ is -0.1790 ( $t$-value $=-5.12$ ) and the average excess $\beta_{i l, 1}$ is -0.2781 ( $t$-value $=-5.99$ ). Thus, while less liquid firms exhibit greater reduction in liquidity risk, stock splits also lower liquidity risk for the relatively more liquid firms that have trades every day prior to the splits. For the latter group, the liquidity risk reduction could be due to the fact that stock splits bring in more small, uninformed trades, as Schultz (2000) and Easley, O'Hara, and Saar (2001) show, and reduce the possibility of intraday trading discontinuity.

For the high-trading-discontinuity subsample, the average reduction of 0.4696 in liquidity beta translates into an average reduction of $4.37 \%$ points per annum in the cost of equity, which is about $21.7 \%$ of the group's presplit average cost of equity capital of $20.16 \%$ per annum. Similarly, for the low-trading-discontinuity subsample, the reduction of 0.1790 in liquidity risk translates into a reduction of 1.6 percentage points per annum, or about $13.8 \%$ of the group's pre-split average cost of equity capital of $11.59 \%$ per annum. Thus, by reducing the liquidity risk that investors face, stock splits generate substantial benefits for the firms. While less liquid firms benefit more from stock splits, firms that have trades every day benefit as well.

\subsection{Liquidity improvement and liquidity risk reduction}

What contributes to the liquidity risk reduction? According to our trading continuity improvement hypothesis, liquidity risk reduction should be related to liquidity improvement, as measured by chgLM12. We are also interested in knowing whether a larger investor base could provide better protection against shocks to market liquidity, thus reducing liquidity risk. To explore these relations, we use the following regression:

$$
\begin{aligned}
& \beta_{i l, 1}=\gamma_{0}+\gamma_{1} \text { lnchgLM12 } 2_{i}+\gamma_{2} \text { Inchginvestor } r_{i}+\gamma_{3} \text { splitfactor }_{i} \\
& +\gamma_{4} \text { Inpreprc }_{i}+\gamma_{5} \text { Inpresz }_{i}+\gamma_{6} \text { Inprebm }_{i}+\gamma_{7} \text { prerunup }_{i} \\
& +\gamma_{8} \text { exchdummy }_{i}+\xi_{i}
\end{aligned}
$$

where $\beta_{i l, 1}$ is firm $i$ 's excess change in liquidity risk (excess with respect to its benchmark firm) and lnchgLM $12_{i}$ is its excess change in LM12. Note that $\operatorname{lnch} g L M 12=\log (1+$ postLM12)- $\log (1+$ preLM12). We also use the split firm's change in LM12 and change in liquidity beta in the regression (7), and obtain similar results. Our experiments show that InchgLM12 performs slightly better than chgLM12 = postLM12-preLM12 in the regression. Also, we have experimented to include Inpreinvestor and Inpreinslown into the regression, and found that they are insignificant. Furthermore, with them in the model, the 
Table 7

Cross-sectional analysis of changes in liquidity risk.

This table reports the results of regressing $\beta_{i l, 1}$, the excess change in liquidity risk, from Eq. (5), on lnchgLM12, the excess change in LM12 (the difference between benchmark-adjusted log (1+postLM12) and benchmark-adjusted log (1+preLM12)), and Inchginvestor, the change in the log (number of shareholders) following the splits, controlling for firm characteristics. For the subsample relations, we set lnchgLM12_D1 = InchgLM12 if preLM12 $\geq 1$, otherwise lnchgLM12_D1 =0; and lnchgLM12_D0 = lnchgLM12 if preLM12 $<1$, otherwise lnchgLM12_D0 =0. Similarly, Inchginvestor_D1 = lnchginvestor if preLM12 $\geq 1$, otherwise lnchginvestor_D1 $=0$; and Inchginvestor_D0 = lnchginvestor if pre$L M 12<1$, otherwise Inchginvestor_D $0=0$. The $t$-values are given below the coefficient estimates.

\begin{tabular}{|c|c|c|}
\hline \multirow[b]{2}{*}{ Model } & \multicolumn{2}{|c|}{ Dependent variable: $\beta_{i l, 1}$} \\
\hline & 1 & 2 \\
\hline lnchgLM12 & $\begin{array}{l}\text { 0.1981 } \\
(3.70)\end{array}$ & \\
\hline lnchgLM12_D1 & & $\begin{array}{l}\text { 0.1351 } \\
(2.16)\end{array}$ \\
\hline InchgLM12_D0 & & $\begin{array}{l}\text { 0.3527 } \\
(3.18)\end{array}$ \\
\hline Inchginvestor & $\begin{array}{l}-0.0410 \\
(-0.58)\end{array}$ & \\
\hline Inchginvestor_D1 & & $\begin{array}{l}-0.2067 \\
(-1.35)\end{array}$ \\
\hline Inchginvestor_D0 & & $\begin{array}{l}-0.0033 \\
(-0.04)\end{array}$ \\
\hline splitfactor & $\begin{array}{l}-0.0818 \\
(-0.87)\end{array}$ & $\begin{array}{l}-0.0886 \\
(-0.94)\end{array}$ \\
\hline Inpreprc & $\begin{array}{l}-0.1653 \\
(-1.17)\end{array}$ & $\begin{array}{l}-0.1554 \\
(-1.10)\end{array}$ \\
\hline Inpresz & $\begin{array}{l}0.0928^{* *} \\
(2.32)\end{array}$ & $\begin{array}{l}0.0960 * * \\
(2.39)\end{array}$ \\
\hline Inprebm & $\begin{array}{l}0.2002^{* * *} \\
(3.57)\end{array}$ & $\begin{array}{l}0.1990^{* * *} \\
(3.55)\end{array}$ \\
\hline prerunup & $\begin{array}{l}-0.1359^{* *} \\
(-2.19)\end{array}$ & $\begin{array}{l}-0.1423^{* *} \\
(-2.29)\end{array}$ \\
\hline exchdummy & $\begin{array}{l}0.1321 \\
(1.29)\end{array}$ & $\begin{array}{l}0.1218 \\
(1.19)\end{array}$ \\
\hline intercept & $\begin{array}{l}0.1186 \\
(0.30)\end{array}$ & $\begin{array}{l}0.0522 \\
(0.13)\end{array}$ \\
\hline Adj. $R^{2}$ & 0.0166 & 0.0172 \\
\hline$N$ & 3,017 & 3,017 \\
\hline
\end{tabular}

$* * *, * *, *$ Significant at the $1 \%, 5 \%$, and $10 \%$ level, respectively.

overall fit of the regression, in terms of adjusted $R^{2}$, declines and lnchgLM12 becomes less significant. For these reasons, we do not include them in Eq. (7).

Table 7 reports the regression results. Model 1 shows that $\beta_{i l, 1}$ is positively and significantly related to lnchgLM12, suggesting that the splits that induce more liquidity improvement have more liquidity risk reduction. However, $\beta_{i l, 1}$ is insignificantly related to Inchginvestor, which implies that the reduction in liquidity risk following the splits is not related to changes in the investor base.

In model 2, we decompose InchgLM12 into InchgLM12_D1 and InchgLM12_D0, and similarly Inchginvestor into lnchginvestor_D1 and lnchginvestor_D0, for examining the subsample relations. ${ }^{8}$ The results show

${ }^{8}$ InchgLM12_D1 = InchgLM12 if preLM12 $\geq 1$, otherwise lnchgLM12_ $D 1=0$; and InchgLM12_D0 = InchgLM12 if preLM $12<1$, otherwise lnchgLM12_D0 $=0$. Similarly, $\quad$ Inchginvestor_D1 = lnchginvestor if that the liquidity risk reduction is significantly related to the liquidity improvement in both the preLM12 $\geq 1$ and preLM $12<1$ subsamples. Again, changes in liquidity risk are not related to changes in the investor base in either subsample.

We next turn to the split announcement effect on stock returns and test whether the announcement returns are correlated with changes in liquidity levels and changes in liquidity risk.

\section{Split announcement returns and liquidity improvements}

We measure stock price reactions, adjusted for marketwide movements, over the three days surrounding the split declaration date (day 0) as the split announcement effect on stock returns. Specifically, we use both the compounded benchmark-adjusted return,

$\operatorname{annBAR}_{i}=\prod_{t=-1}^{1}\left(1+R E T_{i, t}\right)-\prod_{t=-1}^{1}\left(1+R E T_{b i, t}\right)$

and the compounded market-adjusted return,

$\operatorname{annMAR}_{i}=\prod_{t=-1}^{1}\left(1+R E T_{i, t}\right)-\prod_{t=-1}^{1}\left(1+\right.$ MKTRET $\left._{t}\right)$

where $R E T_{i, t}$ is the return on firm $i$ on day $t, R E T_{b i, t}$ is its benchmark firm's return on day $t$, and $M_{K T R E T_{t}}$ is the return on day $t$ on the CRSP value-weighted market portfolio, including NYSE/AMEX/Nasdaq stocks. Since the results are virtually the same, our discussion focuses on the benchmark-adjusted returns.

Consistent with previous studies, we find that the market responds positively to the split announcement-the average three-day benchmark-adjusted return for our sample of 3,721 stock splits over days -1 to +1 is a significant $3.30 \%$. The average three-day market-adjusted return is $3.28 \%$, which is also significantly different from zero. This split announcement return is similar to those found in previous studies (see, e.g., Grinblatt, Masulis, and Titman, 1984; Ikenberry, Rankine, and Stice, 1996).

For the firms with preLM12 $\geq 1$, the average excess return is $4.88 \%$, which is significantly larger than the average excess return of $2.73 \%$ for the firms with preLM $12<1$. The results suggest that the market response to the split announcement is much stronger for less liquid firms.

Next, we examine whether the benchmark-adjusted announcement return is related to the excess change in the liquidity level, as measured by $\operatorname{lnchgLM12}$, and to the excess change in liquidity risk, as estimated by $\beta_{i l, 1}$ from Eq. (5), using the following regression:

$$
\begin{aligned}
& \text { annBAR }_{i}=a_{0}+a_{1} \text { lnchgLM } 12_{i}+a_{2} \beta_{i l, 1}+a_{3} \text { splitfactor }_{i}+a_{4} \text { Inpreprc }_{i} \\
& +a_{5} \text { Inpresz }_{i}+a_{6} \text { Inprebm }_{i}+a_{7} \text { prerunup }_{i}+a_{8}{\text { InpreLM } 12_{i}} \\
& +a_{8} \beta_{i l, 0}+a_{9} \text { lnchginvestor }_{i}+a_{10} \text { Inpreinslown }_{i}+u_{i}
\end{aligned}
$$

(footnote continued)

preLM12 $\geq 1$, otherwise lnchginvestor_D1 =0; and Inchginvestor $D 0=$ lnchginvestor if preLM $12<1$, otherwise lnchginvestor_D0 $=0$. 
Note that many of the explanatory variables on the right-hand side of Eq. (8) have been shown in prior research to affect split announcement returns. For example, the split factor (splitfactor) has been examined as a proxy for the strength of the signal by Brennan and Copeland (1988), Grinblatt, Masulis, and Titman (1984), and McNichols and Dravid (1990). The book-to-market equity ratio (lnprebm) and firm size (lnpresz) have been examined by Ikenberry, Rankine, and Stice (1996) as cross-sectional determinants of split announcement returns. The pre-split price run-up (prerunup) is used by Grinblatt, Masulis, and Titman (1984) as a proxy for the extent to which the stock price is away from its normal trading range. The change in investor base (Inchginvestor) has been examined by Mukherji, Kim, and Walker (1997) and Amihud, Mendelson, and Uno (1999). And institutional share ownership (Inpreinslown) has been studied by Dennis and Strickland (2003). We control for these variables in testing the relations between annBAR and lnchgLM12 and $\beta_{i l, 1}$.

Table 8 reports the regression results. Model 1 shows that annBAR is significantly and negatively related to both InchgLM12 and $\beta_{i l, 1}$, indicating that the split announcement return is indeed more positive for the firms with a greater decrease in no-trade days and a greater reduction in the liquidity beta following their stock splits. The evidence is consistent with our trading continuity improvement hypothesis, and implies that investors are concerned with stock illiquidity and liquidity risk and reward firms that split their stocks to improve liquidity and to reduce liquidity risk.

For the subsample relations, model 2 reveals that the negative relation between annBAR and InchgLM12 holds only in the preLM12 $\geq 1$ subsample, but the negative relation between annBAR and $\beta_{i l, 1}$ holds only in the preLM12 $<1$ subsample. Thus, InchgLM12 has a significant valuation effect for the less liquid subsample in which there is a significant reduction in no-trade days. But it has an insignificant valuation effect for the relatively liquid subsample in which illiquidity is not an imminent problem. Conversely, the liquidity risk reduction has a significant valuation effect only for the preLM12 $<1$ subsample.

For a robustness check, Table 8 also includes the results of using the market-adjusted announcement return, annMAR, as the dependent variable in Eq. (8) with InchgLM12 as the change in liquidity level and $\beta_{i l, 1}$ as the change in liquidity risk from Eq. (4). The inferences are essentially the same. Nevertheless, the results show that the split announcement returns are more strongly related to the improvements in both the liquidity level and liquidity risk.

Inconsistent with Mukherji, Kim, and Walker (1997), neither the benchmark-adjusted nor market-adjusted split announcement return is related to the expansion of the investor base. We also experiment with Inchginvestor_D1 and lnchginvestor_D0 and find no subsample relations. Thus, our findings suggest that it is not the expanded investor base per se that is material in explaining the split announcement returns; instead, what matters is the extent of liquidity improvement and the degree of liquidity risk reduction brought about by expanded investor trading.
Table 8

Cross-sectional analysis of split announcement returns.

In models 1 and 2, the dependent variable is annBAR, the three-day benchmark-adjusted split announcement returns, and the explanatory variables InchgLM12, $\beta_{i l, 1}$, InpreLM12, and $\beta_{i l, 0}$ are also benchmarkadjusted. In Models 3 and 4 , the dependent variable is annMAR, the market-adjusted split announcement returns, and the explanatory variables InchgLM12, $\beta_{i l, 1}$, InpreLM12, and $\beta_{i l, 0}$ are not benchmarkadjusted. For the subsample relations, we set InchgLM12_D1 =

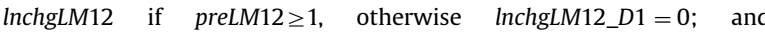
InchgLM12_D0 = InchgLM12 if preLM12 <1, otherwise InchgLM12_D0 =0. Similarly, $\quad \beta_{i l, 1 \_D 1}=\beta_{i l, 1}$ if preLM12 $\geq 1$, otherwise $\beta_{i l, 1 \_D 1=0}$; and $\beta_{i l, 1 \_} D 0=\beta_{i l, 1}$ if preLM12 $<1$, otherwise $\beta_{i l, 1 \_} D 0=0$. The $t$-values are given below the coefficient estimates.

\begin{tabular}{|c|c|c|c|c|}
\hline \multirow[b]{2}{*}{ Model } & \multicolumn{2}{|c|}{$\begin{array}{c}\text { Dependent variable: } \\
\text { annBAR }\end{array}$} & \multicolumn{2}{|c|}{$\begin{array}{c}\text { Dependent variable: } \\
\text { annMAR }\end{array}$} \\
\hline & 1 & 2 & 3 & 4 \\
\hline InchgLM12 & $\begin{array}{l}-0.5802^{* * *} \\
(-2.97)\end{array}$ & & $\begin{array}{l}-0.8154^{* * *} \\
(-4.25)\end{array}$ & \\
\hline lnchgLM12_D1 & & $\begin{array}{l}-0.7126^{* * *} \\
(-3.20)\end{array}$ & & $\begin{array}{l}-0.8741^{* * *} \\
(-4.44)\end{array}$ \\
\hline InchgLM12_D0 & & $\begin{array}{l}-0.1814 \\
(-0.48)\end{array}$ & & $\begin{array}{l}-0.2204 \\
(-0.26)\end{array}$ \\
\hline$\beta_{i l, 1}$ & $\begin{array}{l}-0.1392^{*} \\
(-1.77)\end{array}$ & & $\begin{array}{l}-0.2227^{* *} \\
(-2.52)\end{array}$ & \\
\hline$\beta_{i l, 1 \_D 1}$ & & $\begin{array}{l}-0.1176 \\
(-0.94)\end{array}$ & & $\begin{array}{l}-0.0924 \\
(-0.71)\end{array}$ \\
\hline$\beta_{i l, 1 \_D 0}$ & & $\begin{array}{l}-0.1558 * \\
(-1.80)\end{array}$ & & $\begin{array}{l}-0.2722^{* * *} \\
(-2.84)\end{array}$ \\
\hline splitfactor & $\begin{array}{l}1.2451^{* * *} \\
(4.01)\end{array}$ & $\begin{array}{l}1.2308^{* * *} \\
(3.96)\end{array}$ & $\begin{array}{l}1.2446^{* * *} \\
(4.65)\end{array}$ & $\begin{array}{l}1.2453^{* * *} \\
(4.66)\end{array}$ \\
\hline Inpreprc & $\begin{array}{l}-2.8931^{* * *} \\
(-6.04)\end{array}$ & $\begin{array}{l}-2.8647^{* * *} \\
(-5.98)\end{array}$ & $\begin{array}{l}-2.8439^{* * *} \\
(-6.95)\end{array}$ & $\begin{array}{l}-2.8486^{* * *} \\
(-6.96)\end{array}$ \\
\hline Inpresz & $\begin{array}{l}-0.0205 \\
(-0.12)\end{array}$ & $\begin{array}{l}-0.0152 \\
(-0.09)\end{array}$ & $\begin{array}{l}0.0350 \\
(0.29)\end{array}$ & $\begin{array}{l}0.0365 \\
(0.31)\end{array}$ \\
\hline Inprebm & $\begin{array}{l}-1.2164^{* * *} \\
(-6.31)\end{array}$ & $\begin{array}{l}-1.2139^{* * *} \\
(-6.30)\end{array}$ & $\begin{array}{l}-0.9737^{* * *} \\
(-6.59)\end{array}$ & $\begin{array}{l}-0.9813^{* * *} \\
(-6.64)\end{array}$ \\
\hline prerunup & $\begin{array}{l}0.5359^{* * *} \\
(2.66)\end{array}$ & $\begin{array}{l}0.5268^{* * *} \\
(2.61)\end{array}$ & $\begin{array}{l}0.2378 \\
(1.47)\end{array}$ & $\begin{array}{l}0.2474 \\
(1.53)\end{array}$ \\
\hline InpreLM12 & $\begin{array}{l}0.3380^{* * *} \\
(2.64)\end{array}$ & $\begin{array}{l}0.3324^{* * *} \\
(2.59)\end{array}$ & $\begin{array}{l}0.0048 \\
(0.74)\end{array}$ & $\begin{array}{l}0.0043 \\
(0.66)\end{array}$ \\
\hline$\beta_{i l, 0}$ & $\begin{array}{l}-0.2257^{* *} \\
(-2.20)\end{array}$ & $\begin{array}{l}-0.2297^{* *} \\
(-2.23)\end{array}$ & $\begin{array}{l}-0.4454^{* * *} \\
(-3.91)\end{array}$ & $\begin{array}{l}-0.4211^{\text {*** }} \\
(-3.66)\end{array}$ \\
\hline Inchginvestor & $\begin{array}{l}0.0478 \\
(0.40)\end{array}$ & $\begin{array}{l}0.0548 \\
(0.46)\end{array}$ & $\begin{array}{l}-0.2161 \\
(-1.13)\end{array}$ & $\begin{array}{l}-0.2078 \\
(-1.09)\end{array}$ \\
\hline Inpreinslown & $\begin{array}{l}-0.7510^{* * *} \\
(-3.48)\end{array}$ & $\begin{array}{l}-0.7349^{* * *} \\
(-3.40)\end{array}$ & $\begin{array}{l}-0.9435^{* * *} \\
(-5.20)\end{array}$ & $\begin{array}{l}-0.9479 * * * \\
(-5.21)\end{array}$ \\
\hline intercept & $\begin{array}{l}10.5074^{* * *} \\
(7.14)\end{array}$ & $\begin{array}{l}10.3491^{* * *} \\
(7.00)\end{array}$ & $\begin{array}{l}9.9959^{* * *} \\
(8.03)\end{array}$ & $\begin{array}{l}9.9838^{* * *} \\
(8.02)\end{array}$ \\
\hline Adj. $R^{2}$ & 0.0856 & 0.0855 & 0.1061 & 0.1062 \\
\hline
\end{tabular}

***, ${ }^{* *},{ }^{*}$ Significant at the $1 \%, 5 \%$, and $10 \%$ level, respectively.

\section{Conclusions}

Despite extensive research on stock splits, Easley, O'Hara, and Saar (2001) note that "it remains a puzzle why companies ever split their shares." To resolve the puzzle, we propose and test the trading continuity improvement hypothesis, which asserts that managers of firms facing some possibility of trading discontinuity can use stock splits to attract more uninformed trading, which allows market makers to provide liquidity services at lower costs. With lower trading costs, investors' propensity to trade increases, and investors face reduced liquidity risk. We examine a large sample of stock splits and find, consistent with our hypothesis, that the incidence of no 
trading decreases, implying lower latent costs of trading, and that liquidity risk is mitigated following the splits.

Because stock splits improve trading continuity and alleviate liquidity risk, investors require a lower liquidity premium, resulting in a lower cost of equity capital. Our analysis suggests that, on average, liquidity improvements reduce the cost of equity capital by $17.3 \%$, or 2.42 percentage points per annum. Thus, the economic benefits of stock splits are nontrivial. While less liquid firms benefit more from stock splits, firms that trade every day benefit as well.

Furthermore, we find that firms facing more frequent trading discontinuities choose a higher split factor and experience greater liquidity improvements. And the split announcement returns tend to be higher for firms with a larger decline in no-trade days and for firms with a greater reduction in liquidity risk.

Overall, our study provides an explanation with economic benefits for why companies split their shares. Our findings support managers' view and Muscarella and Vetsuypens' (1996) findings that stock splits are intended to improve liquidity. Also, in line with Lesmond, Ogden, and Trzcinka (1999), Lesmond (2005), Liu (2006), and Bekaert, Harvey, and Lundblad (2007), our study highlights the importance of using trading discontinuity to measure liquidity.

\section{References}

Admati, A., Pfleiderer, P., 1988. A theory of intraday patterns: volume and price variability. Review of Financial Studies 1, 3-40.

Amihud, Y., 2002. Illiquidity and stock returns: cross-section and timeseries effects. Journal of Financial Markets 5, 31-56.

Amihud, Y., Mendelson, H., 1986. Asset pricing and the bid-ask spread. Journal of Financial Economics 17, 223-249.

Amihud, Y., Mendelson, H., Uno, J., 1999. Number of shareholders and stock prices: evidence from Japan. Journal of Finance 54, 1169-1184.

Amihud, Y., Mendelson, H., Pedersen, L., 2005. Liquidity and asset prices. Foundation and Trends in Finance 1, 269-364.

Angel, J., 1997. Tick size, share prices, and stock splits. Journal of Finance $52,655-681$.

Baker, H., Gallagher, P., 1980. Management's view of stock splits. Financial Management 9, 73-77.

Baker, H., Powell, G., 1993. Further evidence on managerial motives for stock splits. Quarterly Journal of Business and Economics 32, 20-31.

Ball, R., Kothari, S.P., 1989. Nonstationary expected returns: implications for tests of market efficiency and serial correlation in returns. Journal of Financial Economics 25, 51-74.

Bekaert, G., Harvey, C.R., Lundblad, C.T., 2007. Liquidity and expected returns: lessons from emerging markets. Review of Financial Studies 20, 1783-1831.

Blume, M., 1975. Betas and their regression tendencies. Journal of Finance 30, 785-795.

Brennan, M., Copeland, T., 1988. Stock splits, stock prices, and transaction costs. Journal of Financial Economics 22, 83-101.

Brennan, M., Hughes, P., 1991. Stock prices and the supply of information. Journal of Finance 46, 1665-1691.

Conroy, R., Harris, R., Benet, B., 1990. The effects of stock splits on bid-ask spreads. Journal of Finance 45, 1285-1295.

Copeland, T., 1979. Liquidity changes following stock splits. Journal of Finance 34, 115-141.

Dennis, P., Strickland, D., 2003. The effect of stock splits on liquidity and excess returns: evidence from shareholder ownership composition. Journal of Financial Research 26, 355-370.

Dolley, J.C., 1933. Common-stock split-ups-motives and effects. Harvard Business Review 12, 70-81.
Dyl, E., Elliott, W., 2006. The share price puzzle. Journal of Business 79 2045-2066.

Easley, D., O’Hara, M., Saar, G., 2001. How stock splits affect trading: a microstructure approach. Journal of Financial and Quantitative Analysis 36, 25-51.

Fama, E.F., Fisher, L., Jensen, M., Roll, R., 1969. The adjustment of stock prices to new information. International Economic Review 10, $1-21$.

Fama, E.F., French, K.R., 1993. Common risk factors in the returns on stocks and bonds. Journal of Financial Economics 33, 3-56.

Fama, E.F., French, K.R., 1996. Multifactor explanations of asset pricing anomalies. Journal of Finance 51, 55-84.

Fama, E.F., French, K.R., 2002. Testing trade-off and pecking order predictions about dividends and debt. Review of Financial Studies 15, $1-33$.

Fernando, C., Krishnamurthy, S., Spindt, P., 1999. Is share price related to marketability? Evidence from mutual fund share splits. Financial Management 28, 54-67.

Gray, S.F., Smith, T., Whaley, R.E., 2003. Stock splits: implications for investor trading costs. Journal of Empirical Finance 10, 271-303.

Grinblatt, M., Masulis, R., Titman, S., 1984. The valuation effects of stock splits and stock dividends. Journal of Financial Economics 13, 461-490.

Harris, L., 1990. Statistical properties of the Roll serial covariance bid/ask spread estimator. Journal of Finance 45, 579-590.

Harris, L., 1996. Does a large minimum price variation encourage order exposure? Unpublished working paper, University of Southern California.

Hasbrouck, J., 2005. Trading costs and returns for US equities: the evidence from daily data. Unpublished working paper, New York University.

Ikenberry, D., Rankine, G., Stice, E., 1996. What do stock splits really signal? Journal of Financial and Quantitative Analysis 31,357-375.

Kadapakkam, R., Krishnamurthy, S., Tse, Y., 2005. Stock splits, broker promotion and decimalization. Journal of Financial and Quantitative Analysis 40, 873-895.

Kyle, A.S., 1985. Continuous auctions and insider trading. Econometrica 53, 1315-1335.

Lakonishok, J., Lev, B., 1987. Stock splits and stock dividends: why, who, and when. Journal of Finance 42, 913-932.

Lamoureux, C., Poon, P., 1987. The market reaction to stock splits. Journal of Finance $42,1347-1370$.

Lesmond, D., 2005. Liquidity of emerging markets. Journal of Financial Economics 77, 411-452.

Lesmond, D., Ogden, J., Trzcinka, C., 1999. A new estimate of transaction costs. Review of Financial Studies 12, 1113-1141.

Lipson, M., 1999. Stock splits, liquidity and limit orders. Unpublished working paper, New York Stock Exchange.

Liu, W., 2006. A liquidity-augmented capital asset pricing model. Journal of Financial Economics 82, 631-671.

Maloney, M., Mulherin, H., 1992. The effects of splitting on the ex: a microstructure reconciliation. Financial Management 21, 44-59.

McNichols, M., Dravid, A., 1990. Stock dividends, stock splits and signaling. Journal of Finance 45, 857-879.

Merton, R., 1987. A simple model of capital market equilibrium with incomplete information. Journal of Finance 42, 483-510.

Mukherji, S., Kim, Y., Walker, M., 1997. The effect of stock splits on the ownership structure of firms. Journal of Corporate Finance 3, 167-188.

Muscarella, C., Vetsuypens, M., 1996. Stock splits: signaling or liquidity? The case of ADR 'solo-splits'. Journal of Financial Economics 42, 3-26.

Pastor, L., Stambaugh, R.F., 2003. Liquidity risk and expected stock returns. Journal of Political Economy 111, 642-685.

Roll, R., 1984. A simple implicit measure of the effective bid-ask spread in an efficient market. Journal of Finance 39, 1127-1139.

Scholes, M., Williams, J., 1977. Estimating betas from nonsynchronous data. Journal of Financial Economics 5, 309-327.

Schultz, P., 2000. Stock splits, tick size and sponsorship. Journal of Finance 55, 429-450.

So, R., Tse, Y., 2000. Rationality of stock splits: target price habit hypothesis. Review of Quantitative Finance and Accounting 14, 67-84.

Stoll, H., 1989. Inferring the components of the bid-ask spread: theory and empirical tests. Journal of Finance 44, 115-134. 